Article

\title{
Comparison of Turbocharging and Pressure Wave Supercharging of a Natural Gas Engine for Light Commercial Trucks and Vans
}

\author{
Norbert Zsiga ${ }^{1, *(0)}$, Mario A. Skopil ${ }^{2}$, Moyu Wang ${ }^{1}$, Daniel Klein ${ }^{3}\left(\mathbb{D}\right.$ and Patrik Soltic ${ }^{1}$ \\ 1 Automotive Powertrain Technologies Laboratory, Empa Swiss Federal Laboratories for Materials Science and \\ Technology, 8600 Dübendorf, Switzerland; moyu.wang@empa.ch (M.W.); patrik.soltic@empa.ch (P.S.) \\ 2 Antrova AG, Hofwisenstrasse 13, 8260 Stein am Rhein, Switzerland; mario.skopil@antrova.com \\ 3 FPT Motorenforschung AG, Schlossgasse 2, 9320 Arbon, Switzerland; daniel.klein@fptindustrial.com \\ * Correspondence: norbert.zsiga@empa.ch
}

Citation: Zsiga, N.; Skopil, M.A.; Wang, M.; Klein, D.; Soltic, P.

Comparison of Turbocharging and Pressure Wave Supercharging of a Natural Gas Engine for Light Commercial Trucks and Vans. Energies 2021, 14, 5306. https:// doi.org/10.3390/en14175306

Academic Editor: Silvia Marelli

Received: 13 July 2021

Accepted: 16 August 2021

Published: 26 August 2021

Publisher's Note: MDPI stays neutral with regard to jurisdictional claims in published maps and institutional affiliations.

Copyright: (C) 2021 by the authors. Licensee MDPI, Basel, Switzerland. This article is an open access article distributed under the terms and conditions of the Creative Commons Attribution (CC BY) license (https:// creativecommons.org/licenses/by/ $4.0 /)$.

\begin{abstract}
To increase the efficiency of a natural gas engine, the use of a Miller camshaft was analysed. To avoid a decline in the low-end torque and also in the transient response, a pressure wave supercharger (Comprex ${ }^{\mathrm{TM}}$ ) was compared to the conventional single-stage turbocharger. The analyses for this conceptual comparison were performed experimentally, and the data were then used to run simulations of driving cycles for light commercial vehicles. A torque increase of $49 \%$ resulted at $1250 \mathrm{rpm}$ when the Comprex ${ }^{\mathrm{TM}}$ was used in combination with a Miller camshaft. Despite the Miller camshaft, the Comprex ${ }^{\mathrm{TM}}$ transient response was still faster than the turbocharged engine. Using the same camshaft, the turbocharged engine took 2.5-times as long to reach the same torque. Water injection was used to increase the peak power output while respecting the temperature limitations. As the Comprex ${ }^{\mathrm{TM}}$ enables engine braking by design, we show that the use of friction brakes was reduced by two-thirds. Finally, a six-times faster catalyst warmup and an up to $90{ }^{\circ} \mathrm{C}$ higher exhaust gas temperature at the three-way catalytic converter added to the benefits of using the Comprex ${ }^{\mathrm{TM}}$ supercharger. The known drawbacks of the Comprex ${ }^{\mathrm{TM}}$ superchargers were solved due to a complete redesign of the machine, which is described in detail.
\end{abstract}

Keywords: turbocharging; pressure wave supercharging; boosting; low-end torque; Miller valve timing; exhaust aftertreatment; transient operation; exhaust brake; Comprex; water injection

\section{Introduction}

The Pressure Wave Supercharger (PWS) is one possibility besides the turbocharger and compressor to supercharge a combustion engine. The PWS has been used to supercharge diesel engines since the 1940s. At that time, the Brown Boveri Company (BBC) in Baden Switzerland started producing a PWS, the so-called Comprex ${ }^{\mathrm{TM}}$ (Comprex is now a trademark of the Antrova AG subsidiary 3 prex AG, Switzerland). PWS applications were first developed in the 1940s as additional stages for locomotive gas turbines by the BBC. Between 1947 and 1955, the ITE Circuit Breaker \& Co in the USA under the leadership of the BBC produced units and successfully tested them on diesel engines [1]. The machine itself is therefore much more recent than the turbocharger, which has now existed for 116 years [2]. Eisele [3] detailed how a PWS was used in a passenger car diesel engine in order to overcome the lower specific power from which diesel engines suffered at that time. The PWS was used at former GM subsidiary Opel and by Mazda with 150,000 cars. It was also used on free-running machines [4] without a belt drive. The disadvantage of these rotors, which are driven only by exhaust gas, is that a special air valve is required for starting and that the speed can never be optimally adjusted, especially since the rotor must be braked from a certain operating point, because the rotor speed should not become too fast. This point will be exceeded relatively soon at today's level of supercharging with much exhaust gas energy. 
With an electric drive motor, however, this effect can be used to feed back electricity to the battery. Although the concept seems older, it promises great advantages for combustion engines today, and it was almost used as an electrically powered version (Hybrid Comprex (Hyprex)) in the Mercedes AMG A45 in 2012.

Many investigations have recently been carried out on this PWS; see [5-11]. Despite the various possibilities and many advantages for the downsizing concept [7,12-14], the PWS has so far not been able to assert itself due to cost reasons in the manufacturing of the cell rotor and the "old design" problems.

In general, the main advantages of a pressure wave supercharging system compared to a conventional turbocharging system are:

- $\quad$ Fast boost pressure response (enables downsizing and Miller timing);

- High boost pressure at low engine speed (enables of downsizing and Miller timing);

- The PWS compensates operational height without overspeeding;

- There is no surge limit present in the PWS;

- External high-pressure EGR can be realized simply by adding an additional throttle actuator;

- $\quad$ No (costly) compressor and turbine maps are required, and physical 1D simulation is possible (e.g., GT suite or AVL Boost);

- $\quad$ Live-time lubricated bearings, no impact on engine oil, no blow by and no thrust bearing needed;

- $\quad$ The absence of oil leakages into the intake or exhaust system;

- Any mounting position is possible (no limitation due to oil leakages);

- No danger of oil coking;

- Quick catalyst light-off and lower emissions since the catalytic converter must be placed between the engine and the PWS;

- Low tailpipe exhaust gas temperatures due to scavenging in the rotor;

- The PWS already absorbs the engine noise, and there are lower space and weight requirements for the exhaust silencer.

Besides these numerous advantages, previous applications also suffered from several disadvantages such as cold start and reliability:

- $\quad$ The need for a small pressure drop on the low-pressure part of the intake and exhaust system, respectively;

- The cold-start behaviour of the PWS is difficult due to leakages in the exhaust gas flow;

- High exhaust gas temperatures lead to the deformation of the exhaust gas-side PWS housing and possibly to a jammed rotor;

- $\quad$ Not state-of-the-art.

Thanks to a new concept that was presented in [15], which is further analysed in this study, the cold-start problems, as well as the problem of jammed rotors can be avoided. Furthermore, the design/matching was performed only in the simulation for a given engine, and the charger fit the given engine/given criteria well.

Besides these mentioned advantages and disadvantages of the system, publications often dealt with the control of the PWS, such as $[9,16,17]$, or the design of pressure wave superchargers without the use of 3D CFD or 1D simulations [11]. However, the design schemes are typically compared to 3D CFD code, as, e.g., in [18], and some authors optically measured the velocity field, as well as the shape of the contact surface between the two media in the rotor cells [19].

In this study, a conceptual comparison was carried out, touching on a number of topics that are affected when a PWS is used instead of a turbocharger to give an overview of the numerous areas of improvement. The new Comprex concept was analysed experimentally in combination with a light commercial vehicle natural gas engine. This study is intended to give the reader a comparison with a conventional turbocharged system on a wide range of topics that are impacted by the adaptation of this boosting device. The results described here span from the full-load operation to the part-load efficiency analysis, 
transient operation, fuel consumption in driving cycles and the impacts on the exhaust gas aftertreatment in steady-state and cold-start conditions.

\section{Experimental Setup}

Experiments were performed on a FPT F1C engine with four cylinders and a displacement of 3.0 litres with an increased compression ratio of 16.5. The engine was operated with port-fuel-injected natural gas $(\mathrm{CNG})$ and was controlled to stoichiometric conditions. Table 1 gives an overview of the experimental setup. In order to assess the possibilities to increase its efficiency, the engine had an increased compression ratio, and there was the option to use a camshaft with early intake valve closing (Miller valve timing) instead of the conventional camshaft.

Table 1. Main characteristics of the experimental setup.

\begin{tabular}{cc}
\hline Engine basis & FPT F1C 3.0 litre, CNG version \\
\hline Bore/stroke/number of cylinders & $96.0 \mathrm{~mm} / 104.0 \mathrm{~mm} / 4$ \\
\hline Compression Ratio & 16.5 \\
\hline Fuelling & Port fuel injection of natural gas, Bosch NGI2 injectors \\
\hline Variability in the valve train & None (fixed lift, no valve timing adjustment) \\
\hline Conventional camshaft intake & max. lift 8.5 mm, intake valve closing angle 565 ${ }^{\circ} \mathrm{CA}$ \\
\hline Miller camshaft intake & max. lift 6.1 mm, intake valve closing angle 525 ${ }^{\circ} \mathrm{CA}$ \\
\hline Charge air intercooler & Water/air intercooler, fixed water mass flow rate and \\
constant water inlet temperature
\end{tabular}

The engine was operated using natural gas from the Swiss gas grid, and the gas was analysed using a gas chromatograph (Siemens MicroSAM). Table 2 summarizes the main components and characteristics of the fuel.

Crank angle-based and time-based data were recorded with a Kistler KiBox and the test bench automation system SRH STARS, respectively. The temperatures and pressures were measured at various locations along the intake and exhaust gas flow path, respectively, and, especially, upstream and downstream each catalytic converter and component of the charging devices. The emissions measurement equipment can analyse the exhaust gas upstream and downstream each catalytic converter. 
Table 2. Main components and characteristics of the fuel.

\begin{tabular}{cc}
\hline $\mathrm{CH}_{4}$ & 90.65 vol.-\% \\
$\mathrm{C}_{2}$ & 4.566 vol.-\% \\
$\mathrm{CO}_{2}$ & 1.212 vol.-\% \\
$\mathrm{N}_{2}$ & 0.762 vol.- $\%$ \\
$\mathrm{C}_{3}$ & 0.606 vol.-\% \\
Higher Heating Value & $52.64 \mathrm{MJ} / \mathrm{kg}$ \\
Lower Heating Value & $47.53 \mathrm{MJ} / \mathrm{kg}$ \\
Normal Density & $0.782 \mathrm{~kg} / \mathrm{m}^{3}$ \\
\hline
\end{tabular}

The boosting device and the intake camshaft can be changed and allow the analysis of the performance of the engine with all combinations thereof. Figure 1 shows a photograph of the test bench with the Comprex supercharger installed.
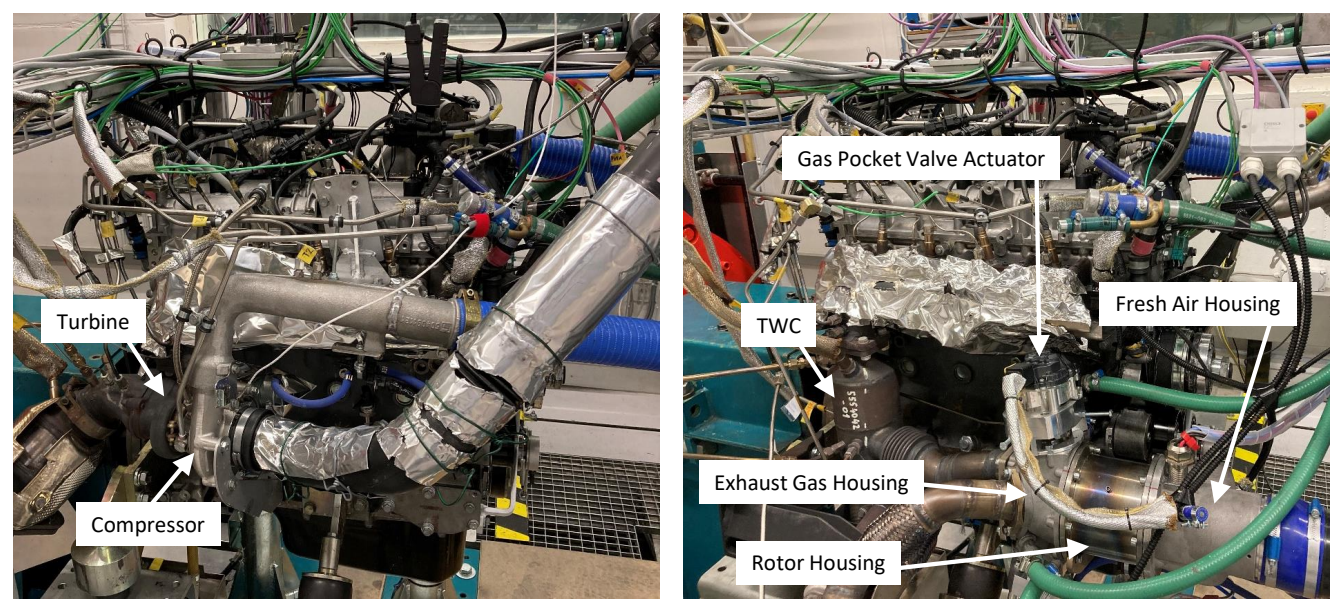

Figure 1. Photographs of the engine equipped with a turbocharger (left) and the Comprex supercharger (right) on the test bench, view from the exhaust side.

\section{The Comprex Pressure Wave Supercharger}

The pressure wave supercharger that was used in this research is shown schematically in Figure 2. The low-pressure side consisted of Channels 1 and 4, whereas the high-pressure side consisted of Channels 2 and 3, respectively.

In pressure wave superchargers, the pressure energy is transferred from the exhaust to the intake side by bringing the two fluids into direct contact for a very short time in long, thin channels. These channels are the so-called rotor cells and are hinted at in the form of grey rectangles in Figure 2. Pressure wave machines use the physical principle that after two media of different pressures are brought into contact, the pressure equalization takes place faster than the mixing of the fluids. In case of the Comprex, the mixing of exhaust gas and fresh air hardly takes place due to the different fluids' densities.

The pressure wave process can basically be divided into two phases: the high-pressure and the low-pressure process. In the high-pressure process, the exhaust gas enthalpy in Channel 3 is used to compress the fresh gas flowing into Channel 2. Part of the enthalpy of the exhaust gas can be passed through the gas pocket, which reduces the pressure in Channel 3 and, therefore, the compression of the fresh gas in Channel 2. In doing so, the pressure in the rotor cells is increased shortly before the start of the low-pressure cycle, which improves the scavenging in the low-pressure process. The aim of the low-pressure process is to purge the rotor cells, which are filled with exhaust gas in the direction of Channel 4 and to fill them with fresh air from Channel 1. Therefore, Channel 4 is not only filled with exhaust gases, but also with fresh air, which is compressed in the high-pressure process, but does not flow into Channel 2. The temperatures of the tailpipe exhaust gas are lower compared to a turbocharged engine due to this scavenging process. 


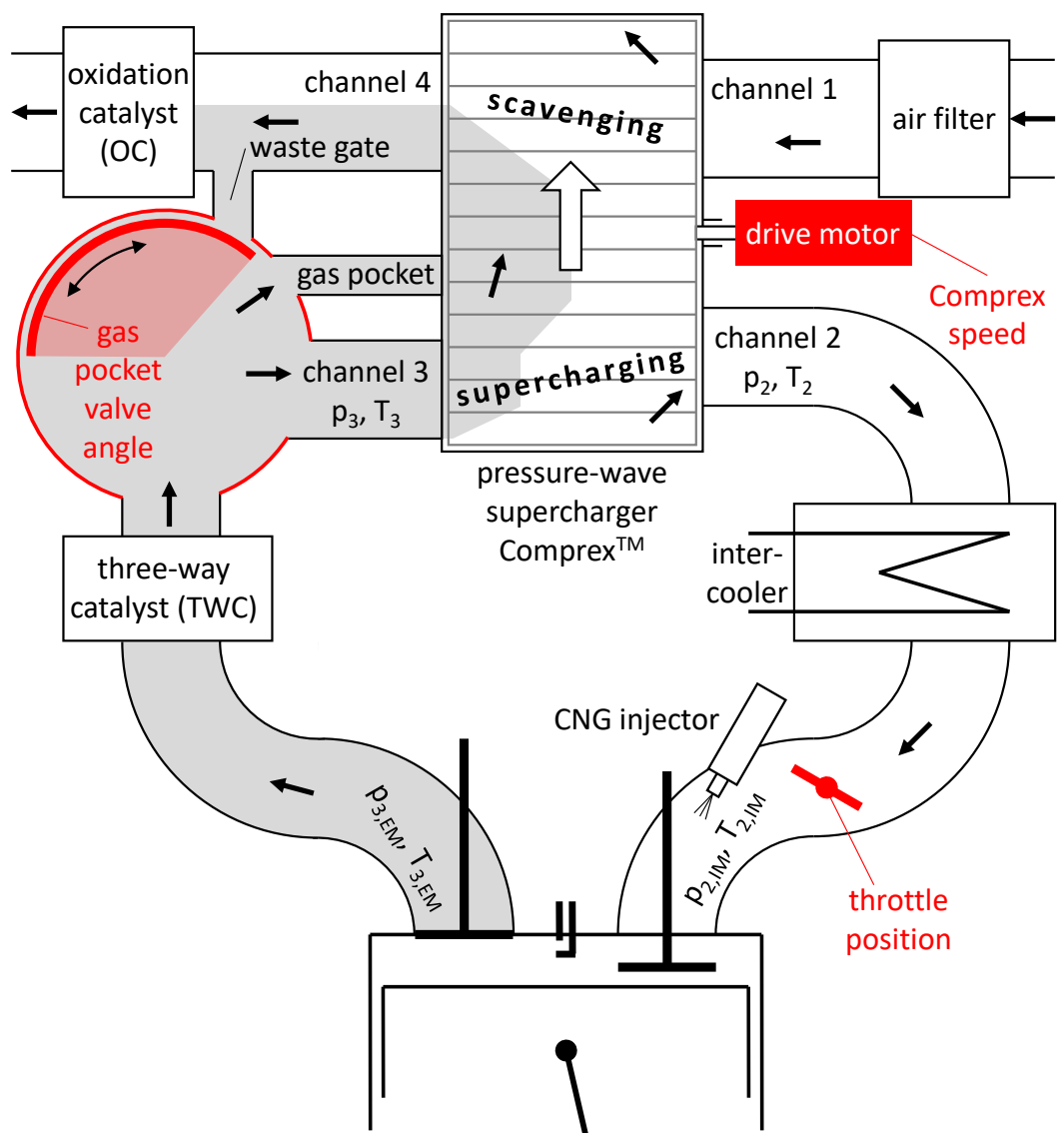

Figure 2. Schematic of the Comprex pressure wave supercharger. The description of the relevant pressures and temperatures is also indicated in the schematic.

The channels (Channel 3, gas pocket, Channel 4, Channel 1 and Channel 2) were all open towards the rotor. Seen from a rotor cell, certain closing and opening angles must be observed so that the timing for the gas dynamics is correct, otherwise the PWS will not work [20]. The channels were also subject to certain inflow and outflow incidence angles during the transition between the rotor and housings, which should not become too large. The channels were not directed towards the rotor with a $90^{\circ}$ angle, as shown in Figure 2. The width of the channels was not chosen arbitrarily due to reasons of noise. If designed appropriately, there would be no need for an exhaust muffler [15].

It must be noted that the schematic shown in Figure 2 only shows half of the Comprex. In reality, what is shown in the schematic is only one "cycle", and and the machine contained two cycles shifted by $180^{\circ}$ around the circumference. There were two gas pocket valves, which could be operated continually and independently from one another with a stepper motor for each valve.

This was the first main difference from previous Comprex designs as this two-cycle design provided the ability to turn off one of the two gas dynamic cycles by closing one of the gas pocket valves completely such that this Comprex functioned as a sequential charging system with VTG turbines. With the old concept, both cycles were always applied, which had an unfavourable influence on the gas dynamics for small mass flows. A possible countermeasure would be the adaptation of the air-side control edges by rotating the air-side housing. This was realized either by turning the entire air-side housing or by means of a round plate with the control edges inside the air housing. It was inevitable that these solutions involved further losses such as secondary flows behind the plate or unfavourable flow conditions between the rotatable plate and the air housing. There were no such losses when one cycle was switched off and one cycle ran with twice the mass flow. For this reason, the elaborate twisting of the control edges was dispensed with in the new concept (see also $[15,21]$ ), and the housing angle that used can be determined in advance 
by simulation or readjusted based on experimental results. When switching off one cycle, it is important to note that the rotor speed must be kept at the same level that exists with twice as much throughput running with both cycles. Therefore, the supercharger can be operated at approximately the same speed level across a wide range of engine speeds.

The second and third main difference compared to previous Comprex designs were the bearing concept and rotor design. These differences are shown schematically in Figure 3. The new concept (right) provided a double-walled aluminium exhaust gas housing, which was cooled by the engine cooling circuit. In this housing, the temperature was low enough such that a bearing could be installed on the exhaust side of the machine.
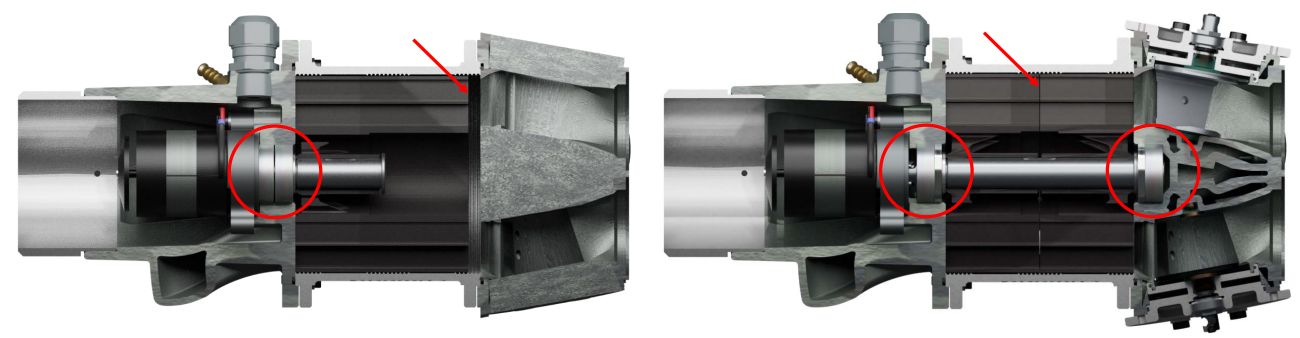

Figure 3. Different Comprex designs. In both designs, the fresh air housing is located on the lefthand side and includes the drive motor, while the exhaust gas housing is located on the right-hand side. The circles indicate the bearing locations, and the arrows point to the location of the gap that compensates the thermal elongation of the rotor. (Left) Old design, bearings only in the air-side housing, one-piece rotor. (Right) New design, one bearing in each housing, two-piece rotor with a central gap.

This is in contrast to the old concept (left) in which a spindle bearing was used on the fresh gas side only since no bearing could be accommodated in the exhaust gas housing, which was up to $1000{ }^{\circ} \mathrm{C}$. The spindle bearing could not be encapsulated, which led to the fact that hot exhaust gas blew the grease out of the bearings, which subsequently failed. With the new concept, this is no longer possible. Hot exhaust gas cannot flow through the bearings as the bearings themselves were fully encapsulated.

In the old concept, the gap at the exhaust gas side had to be rather large when the rotor was cold in order to provide sufficient space for thermal elongation of the rotor. Especially with gasoline and CNG engines with high exhaust gas temperatures, the rotor needed a rather large gap between the exhaust housing and the rotor in the cold state in order to avoid rotor jamming when the machine was at operating temperature. This was of great disadvantage in the cold-start phase since the exhaust gas could flow past the rotor directly from Channel 3 to Channel 4 and, therefore, hardly perform any work. Large gaps between the rotor and the housing led to lower efficiency as the efficiency decreased exponentially with increasing gaps. Small rotor-housing gaps are necessary to ensure that the PWS functions properly [20]. Besides cold-start conditions, the PWS did not work as well, as long as the exhaust gas temperature stayed under a certain level with the old concept.

The new bearing concept enabled the use of a two-part rotor that was divided at its centre. With this new concept, the gaps between the rotor and housing always remained small regardless of the rotor temperature, whereas the central gap decreased and practically closed in operation as the rotor temperature increased. This constant gap between the rotor and housing resulted in the elimination of the cold-start and low-temperature problems. The gap in the middle was different regarding its influence on the system. If one looks at the state variable from cell to cell in the middle gap, they were very similar and only slightly delayed $(0.1389 \mathrm{~ms}$, at $12,000 \mathrm{rpm}$ with 36 cells $)$. The pressure drops were small across the flow direction, and there was also no possibility that exhaust gas or air could flow directly into the respective low-pressure process. The quantity of flow coming out of one cell flowing into the next cell was not lost. There was only a small exchange (shift) from cell to cell. In the overall balance, the rotor area was therefore quite dense, although it was not made from one piece. 
The fourth main difference resulted from the fact that both gas pocket valves and Channel 3 could be closed entirely in motored operation, which could be used to increase the exhaust backpressure and reduce the engine mass flow. This was what enabled a continually adjustable engine brake capability, which at the same time helped avoid a cool down of the catalyst.

The main improvements of the new Comprex concept can be summarised as:

- Performance of a sequential charging system resulting from the possibility of turning off one of the two gas dynamic cycles;

- The use of two encapsulated, maintenance-free bearings was enabled by using a water-cooled exhaust gas housing;

- A split rotor design that eliminated cold-start problems by enabling small rotorhousing gaps at all operating temperatures;

- Continually adjustable engine braking capability by closing all exhaust gas channels.

In the following sections, the operation of the Comprex is optimised and put to the test in various operating conditions.

\section{Engine Operation with a Comprex Supercharger}

For the load control of an engine equipped with this boosting device, there are four independent control inputs: rotor speed, throttle position and both gas pocket valve angles.

Below naturally aspirated full load-as for turbocharged engines-the throttle is used to control the intake manifold pressure. When boost pressure is required, the gas pocket(s) must be closed in order to increase the backpressure and, hence, enable stronger pressure waves that will in turn increase the pressure in Channel 2. The boost pressure can be controlled continually by changing the closed-off cross-section of the gas pocket(s). At low engine speeds, one gas pocket valve is closed completely, forcing all the exhaust gas through half the machine, whereas at higher engine speeds, both gas pocket valve angles are the same. At low engine loads, the gas pocket valve angle can also be chosen to open the wastegate cross-section, allowing the fluid to bypass the machine, further reducing the backpressure. The load control is thus very similar to an engine equipped with sequential turbocharging.

The rotor speed of the Comprex, however, can be chosen freely and has an impact on the steady-state operating conditions. In the following, this impact of the rotor speed is analysed at a low-load and at a high-load operating point.

For a low engine load, the results are shown in Figure 4. The gas pocket valve angles were controlled to lead to a wastegate opening where the pressure downstream the Comprex $\mathrm{p}_{2}$ was equal to 1 bar. When the rotor speed was increased, the rotor power, the exhaust gas backpressure and the EGR rate all increased. The temperature $\mathrm{T}_{2}$, which was measured after compression on the fresh air side, decreased initially, but then increased with increasing EGR rate. However, the differences were small. Given that a high exhaust manifold backpressure and a high rotor power should be avoided to achieve a higher brake efficiency, a rather low speed should be chosen.

For a high engine load, the results are shown in Figure 5. At high engine loads, the resulting EGR rate remained low for all chosen rotor speeds. The trend for the rotor power was the same as for the low-load operating point, and it increases with increasing speed.

There were, however, more significant changes to the exhaust gas backpressure and the temperature $\mathrm{T}_{2}$. The boost pressure remained almost constant as it was controlled to keep the engine torque at a constant $400 \mathrm{Nm}$ (16.8 bar brake mean effective pressure) for all measurements. The exhaust manifold backpressure, on the other hand, changed by approximately 0.1 bar and had a minimum between a rotor speed of 10,000 and 11,000 rpm. The temperature $\mathrm{T}_{2}$ was lowest where the scavenging of the rotor was highest. A reduced scavenging at a too low or too high rotor speed led to a reduced cooling of the rotor, which led to an increase in $\mathrm{T}_{2}$. 

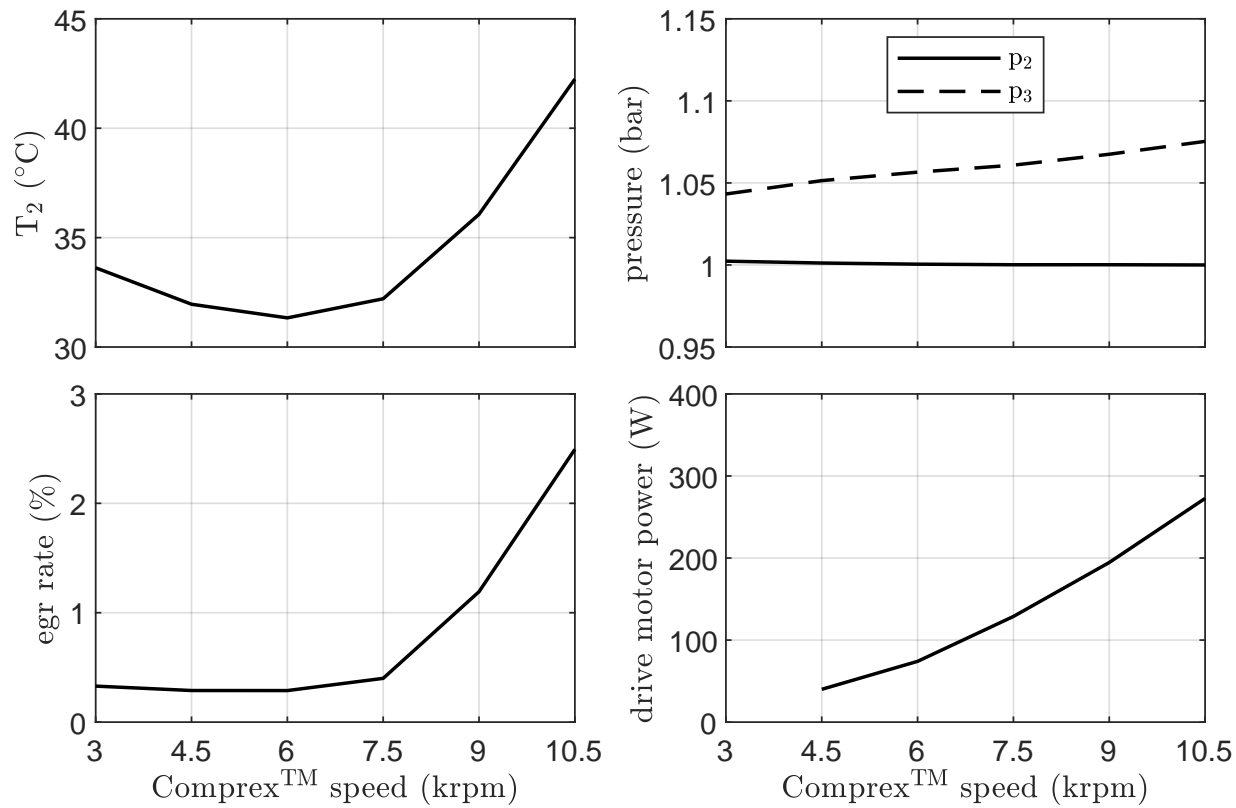

Figure 4. Variation of the rotor speed at $2250 \mathrm{rpm}$ and $50 \mathrm{Nm}$, operation with both cycles.
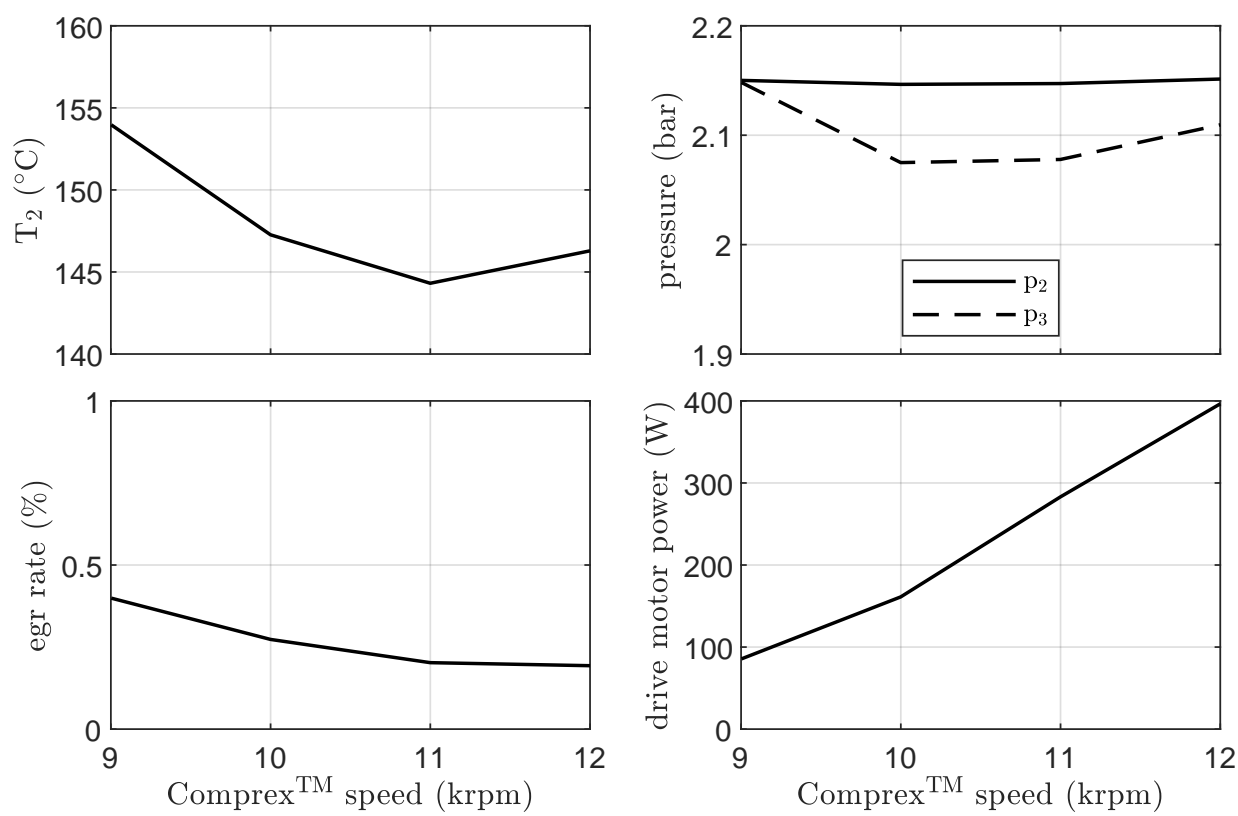

Figure 5. Variation of the rotor speed at $2250 \mathrm{rpm}$ and $400 \mathrm{Nm}$, operation with both cycles.

Notice that there was a rather wide operating range possible for the low-load and also for the high-load operating point. This means that if the rotor speed were temporarily different from the optimal steady-state value, as may be the case during transients, this was not a limiting factor for the operation. For the two operating points at $2250 \mathrm{rpm}$ that were analysed here, rotor speeds of $8500 \mathrm{rpm}$ and 10,500 rpm were chosen for $50 \mathrm{Nm}$ and $400 \mathrm{Nm}$, respectively. It must be kept in mind that during transient operation, this difference in rotational speed must be overcome, and therefore, the rotor speed at high load also had an impact on the selection of the rotor speed at low load.

At other engine speeds, the trend for the EGR rate and tradeoffs (rotor speed vs. $T_{2}$ and $\mathrm{p}_{3}$ ) were basically the same regardless of the fact that at $1250 \mathrm{rpm}$, the Comprex was operated with one cycle rather than two, as for the higher engine speeds.

We performed this analysis at $1250 \mathrm{rpm}, 2250 \mathrm{rpm}$ and $3250 \mathrm{rpm}$ and several engine loads and chose the following rotor speed map, which we interpolated/extrapolated for 
different engine speeds and extrapolated for higher engine loads. We used this speed map for all the following measurements in the entire operation map, at full load, part load, for transient operation, as well as for the analysis of the exhaust gas aftertreatment system.

Figure 6 shows that the difference in rotor speed from $50 \mathrm{Nm}$ to $400 \mathrm{Nm}$ was only $3500 \mathrm{rpm}$ at low engine speeds and lower at higher engine speeds. This was in stark contrast to the use of a turbocharger, where the difference from part load to full load was on the order of several 10,000 rpm instead (depending on the engine size), and the increase resulted from the exhaust gas enthalpy.

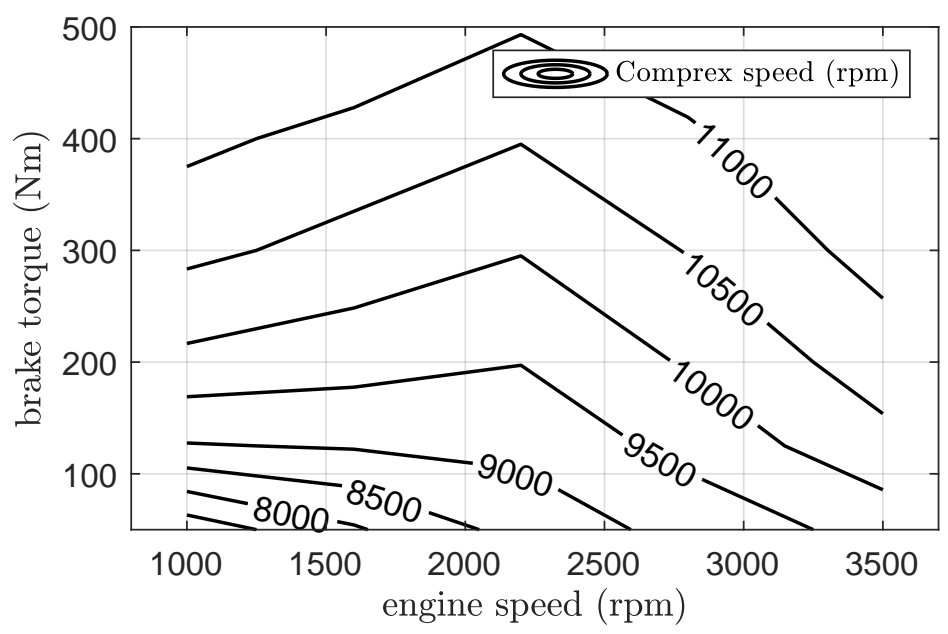

Figure 6. The steady-state rotor speed that was used for the experimental analysis.

\section{Results of Steady-State Operation}

In this section, steady-state operation results for the turbocharged and the pressure wave supercharged engine are presented. At first, the full load data are shown to motivate the combination of the boosting device and camshaft that will be compared subsequently. Furthermore, the increase of the peak engine power output in the presence of temperature limitations by means of water injection is presented. Thereafter, the part-load engine efficiency is compared. For the engine equipped with the Comprex charger, the engine brake operation is also detailed. Finally, the engine maps are used to calculate the fuel consumption of light duty vehicles of different weights equipped with either of the engines in WLTC driving cycles. For convenience, the configurations are abbreviated as described in Table 3 below.

Table 3. Combination of different boosting devices and camshafts and their abbreviations.

\begin{tabular}{ccc}
\hline Boosting Device & Camshaft & Abbreviation \\
\hline Comprex & conventional & CXC \\
Turbocharger & conventional & TCC \\
Comprex & Miller & CXM \\
Turbocharger & Miller & TCM \\
\hline
\end{tabular}

\subsection{Full-Load Operation}

The full-load measurements that were carried out to quantify the performance of both charging systems in all configurations CXC, TCC, CXM and TCM, respectively. The engine speed ranged from $1000 \mathrm{rpm}$ to $3500 \mathrm{rpm}$, and the speed was varied in steps of $250 \mathrm{rpm}$ with the following operating limits:

- Maximum exhaust gas temperature in exhaust runner $880^{\circ} \mathrm{C}$;

- Maximum turbine inlet temperature $900{ }^{\circ} \mathrm{C}$;

- Maximum Comprex inlet temperature $950^{\circ} \mathrm{C}$;

- Maximum temperature of the TWC $950{ }^{\circ} \mathrm{C}$; 
- $\quad$ Maximum cylinder head temperature $250{ }^{\circ} \mathrm{C}$;

- Maximum in-cylinder pressure 150 bar;

- Latest centre of combustion $20^{\circ} \mathrm{CA}$ after top dead centre;

- Knocking should occur in a maximum of $4 \%$ of the cycles.

The centre of combustion and the knock criterion were chosen somewhat arbitrarily. This was done in order to not stress the engine too much (knock criterion) as this is an engine for light duty applications that must have a high durability and to ensure comparability between the different measurements (COC).

Figure 7 shows the maximum brake torque that was achieved with the configurations CXC, CXM, TCC and TCM, respectively. At engine speeds above $2500 \mathrm{rpm}$, the results were similar for all configurations. Both configurations of the turbocharged engines led to results that were practically identical. The CXM configuration resulted in a slightly lower torque because of the slightly higher temperature level of the Comprex compared with the turbocharger. A torque greater than $400 \mathrm{Nm}$ was possible up to $2750 \mathrm{rpm}$ for all configurations, and this was where the maximum cylinder head temperature was first reached. For higher engine speeds, this temperature was also the limiting factor. The engine power output remained constant for each configuration at higher engine speeds, and the torque reduced accordingly. For the turbocharged configurations at low engine speeds, the Miller camshaft led to a significant reduction in low-end torque. Despite the fact that the wastegate was fully closed up to an engine speed of $2250 \mathrm{rpm}$, only at that engine speed, a torque greater than $400 \mathrm{Nm}$ was first achieved due to a lack of boost pressure at lower engine speeds. While the turbocharged engine with the conventional camshaft surpassed $400 \mathrm{Nm}$ at $1750 \mathrm{rpm}$, it was significantly outperformed by the Comprex, even when the Miller camshaft was used. In the CXM configuration, $430 \mathrm{Nm}$ was reached at an engine speed of $1250 \mathrm{rpm}$, and up to engine speeds of $1750 \mathrm{rpm}$, the Comprex was operated with one cycle. In this configuration, the load control actuator was only in its saturation at $1000 \mathrm{rpm}$, i.e., there would still be the potential to increase the boost pressure at all other engine speeds. Further data of the most important temperatures and pressures are compared in Figure 8.

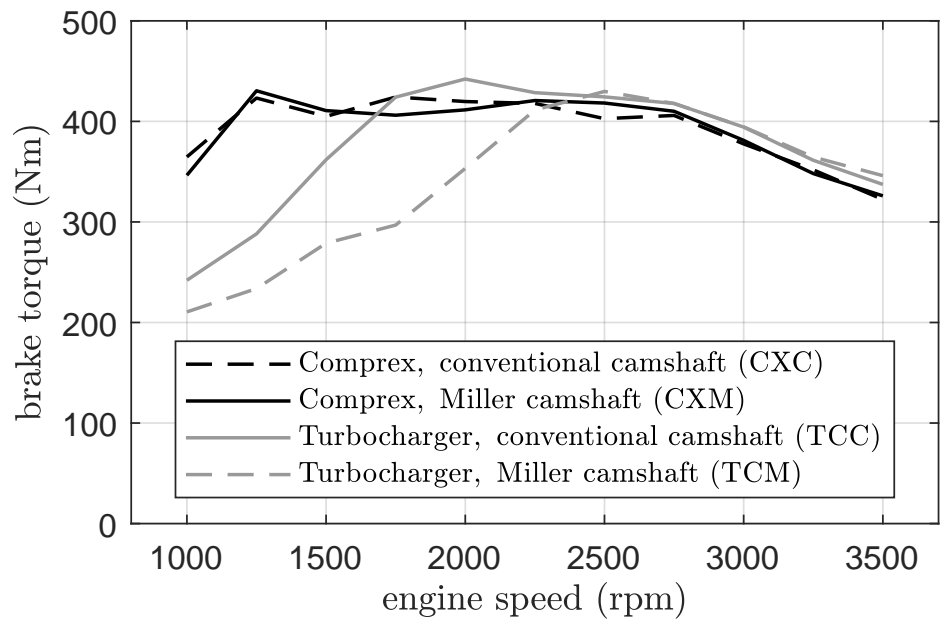

Figure 7. Full-load brake torque results with different charging systems and different camshafts. 

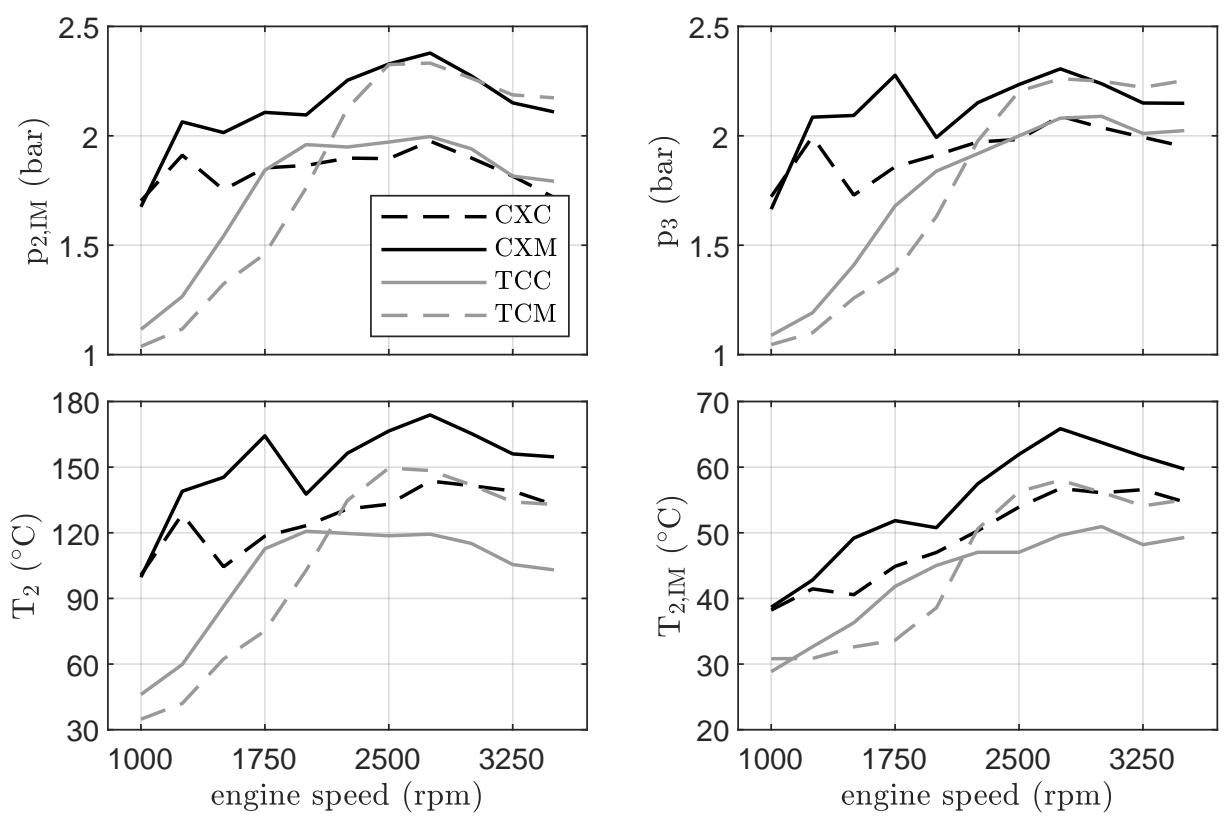

Figure 8. Pressures and temperatures during full-load operation.

The upper plots of Figure 8 show the intake manifold pressure $\mathrm{p}_{2, \mathrm{IM}}$ and the exhaust pressure $\mathrm{p}_{3}$, respectively. Obviously, due to the Miller camshaft, the pressure levels in the case of the CXM concept were much higher. At high engine speeds, when a high brake torque can also be achieved with the TCM configuration, the boost pressure level between the two Miller configurations was similar. At low engine speeds, however, the difference was even larger, since a high torque output can only be reached with the Comprex/Miller configuration. For the TCC concept, the boost pressure was higher than the exhaust gas backpressure up to an engine speed of $2250 \mathrm{rpm}$, whereas for the CXM configuration, this was the case from $2000 \mathrm{rpm}$ to $3250 \mathrm{rpm}$. The bottom plots of the temperatures after compression $T_{2}$ and in the intake manifold $T_{2, I M}$ showed that in the engine speed range where the boost pressure for both Miller concepts was similar, the temperature after compression $\mathrm{T}_{2}$ and the intake manifold temperature $\mathrm{T}_{2, \mathrm{IM}}$ were both higher when the Comprex was used. To some extent, the difference may be reduced by optimizing the Comprex rotor speed for all engine speeds and also by further optimization of the Comprex. However, the maximum engine power output only reduced from $124 \mathrm{~kW}$ (TCC) to $120 \mathrm{~kW}$ (CXM), i.e., a reduction of $3.2 \%$.

To emulate a higher compression efficiency, the intake manifold temperature was reduced from $66{ }^{\circ} \mathrm{C}$ to $42{ }^{\circ} \mathrm{C}$ by adjusting the water mass flow rate of the test bench water/air intercooler. Then, the torque could be increased from $410 \mathrm{Nm}$ to $426 \mathrm{Nm}$ without violating the maximum allowed cylinder head temperature.

These steady-state full-load results showed that the CXM concept outperformed both the TCC and TCM concepts at low engine speeds, but led to a slight reduction in maximum engine power output when the same charge air intercooler was used. Since the turbocharged Miller engine would have a severely impacted drivability and because the desired torque output can be reached with the CXM concept, in the remainder of this paper, mostly the following two configurations are compared:

- Turbocharger with the conventional camshaft (TCC);

- Comprex with the Miller camshaft (CXM).

\subsection{Increase of the Maximum Engine Power Output}

As in all configurations, the cylinder head temperature was the factor that limited the maximum power output, a temperature-reducing measure is presented here. The injection of water is a known measure to reduce the temperature level in an internal combustion 
engine and also to reduce the knock tendency. The engine was equipped with port fuel water injectors to test the effects of water injection on the engine at full load.

In a measurement series at $3000 \mathrm{rpm} / 300 \mathrm{Nm}$, different water/fuel mass ratios were used to analyse the impacts on the combustion. The brake torque was kept constant, while the water/fuel ratio was increased from $0 \%$ to $80 \%$. The water was injected at a pressure 5 bar higher than the intake manifold pressure, and the start of injection was right after the intake valve opening angle. The centre of combustion was corrected for each water/fuel ratio, such that the engine operation was at the onset of knock in each measurement.

Figure 9 shows the effect of the water injection on the combustion parameters. The upper left plot shows that with increasing water/fuel ratio, the centre of combustion could be advanced. This was due to the dilution of the mixture with water vapour, which slowed down the combustion and the cooling effect of the water evaporation. The upper right plot shows the inflammation duration, i.e., the duration from the ignition angle until $5 \%$ of the mixture was combusted. The flame development phase took significantly longer when a higher water/fuel ratio was used. The bottom left plots shows the heat release rate for the five operating conditions, and the earlier combustion start can be seen in the graph. The figure also shows that the peak heat release rate was lower and the combustion duration increased when more water was present during the combustion. The result of these effects on the combustion was a change in the brake efficiency, which peaked at a water/fuel ratio of $40 \%$ and was approximately $0.4 \%$ points higher (i.e., the fuel consumption was about $1 \%$ lower) compared to the operation with no water injection. For higher water/fuel ratios, the combustion duration became less favourable, and the efficiency reduced again, despite the fact that the centre of combustion was closer to $8{ }^{\circ} \mathrm{CA}$.
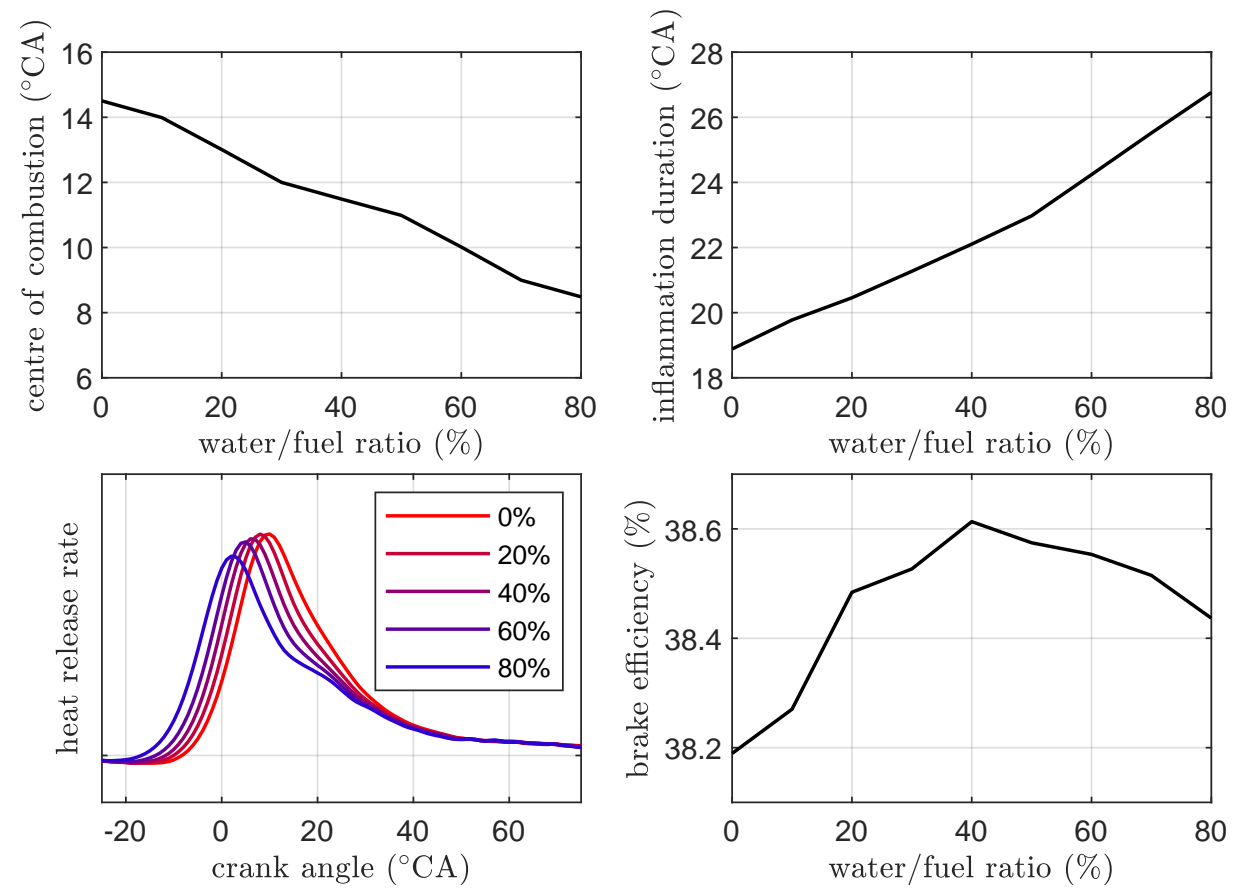

Figure 9. Effects of water injection on the combustion at an engine speed of $3000 \mathrm{rpm}$ and a brake torque of $300 \mathrm{Nm}$. The bottom left plot shows the heat release rates for different water/fuel mass ratios.

During these measurements, the coefficient of variance of the indicated mean effective pressure reduced from $1.53 \%$ without the injection of water to $0.87 \%$ at a water /fuel ratio of $80 \%$.

Figure 10 shows the main influence of water injection on relevant temperatures and raw emissions. The upper left plot shows that the exhaust gas temperature $\mathrm{T}_{3}$, which was measured at the entry of the turbine housing, reduced significantly with an increased 
water/fuel ratio. The cylinder head temperature, which was measured between the exhaust valves, also reduced when a higher water/fuel ratio was used. The bottom left plot shows that the reduction in temperature was accompanied by a reduction in the $\mathrm{NO}_{\mathrm{x}}$ raw emissions. However, due to a more incomplete combustion, the raw emissions of hydrocarbons increased. The correlation between temperature $\mathrm{NO}_{\mathrm{x}}$ and hydrocarbon raw emissions was well supported in other previous studies [22,23].
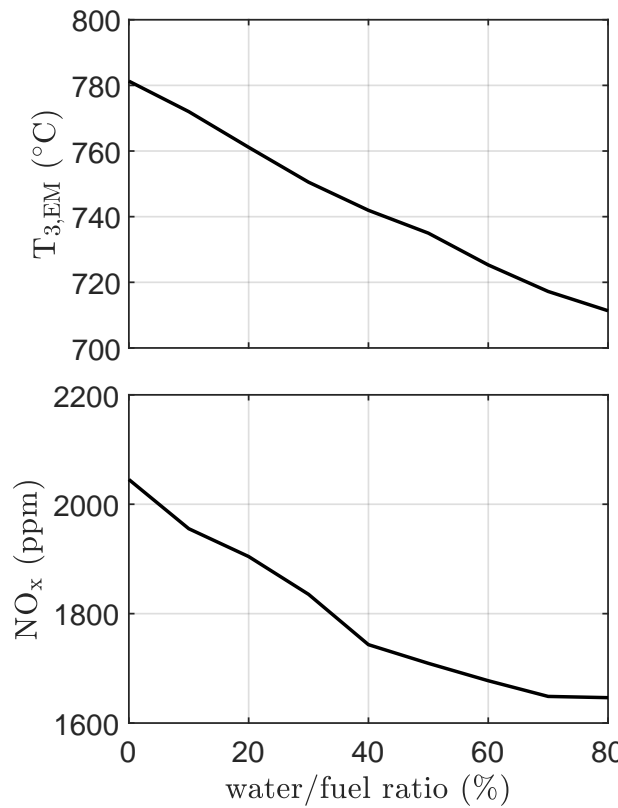
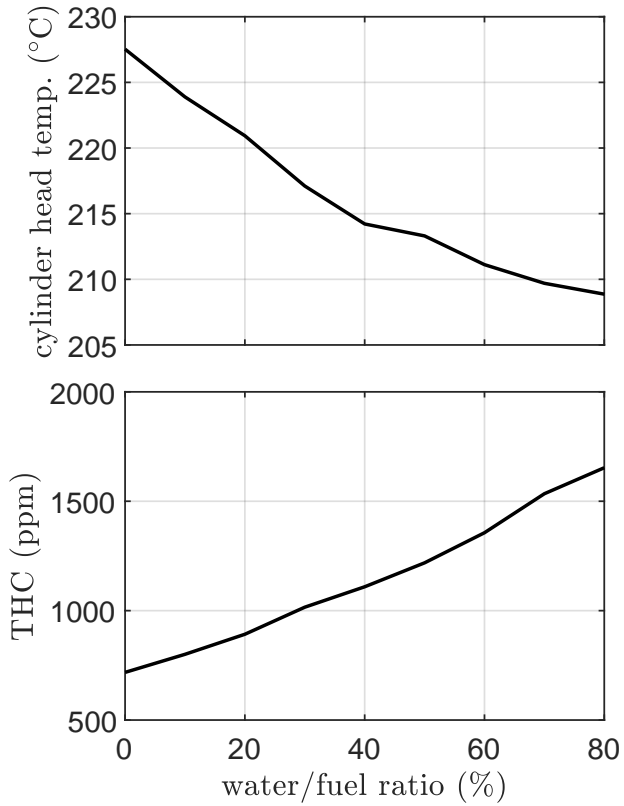

Figure 10. Effects of water injection on the relevant temperatures and engine-out emissions at an engine speed of $3000 \mathrm{rpm}$ and a brake torque of $300 \mathrm{Nm}$.

As the cylinder head temperature was the limiting parameter for this particular engine regarding the maximum power output, this showed that there is a potential to increase the power output. However, it is also true in general that CNG engines, which sometimes are derivates of diesel engines, suffer from limits in the operating temperatures, and water injection is an effective measure to reduce/avoid this problem.

To quantify the possible increase in the engine power output, full-load measurements were made at $2750 \mathrm{rpm}$ for the TCC and the CXC concept with water/fuel ratios of $0 \%$, $25 \%$ and $50 \%$. The results of these measurements are shown in Figure 11. The centre of combustion remained at the chosen limit of $20^{\circ} \mathrm{CA}$ for all measurements, and the intake manifold pressure was increased until the onset of knock was reached.

The upper left plot shows that the brake torque can be increased by $48 \mathrm{Nm}$ and $47 \mathrm{Nm}$ for the CXC and the TCC concept, respectively. The increased boost pressures led to increasing temperatures on the intake side, as shown in the upper right plot. Despite this increase, the exhaust gas temperature, as well as the cylinder head temperature both reduced, as shown in the bottom plots.

These results showed that an increase in the peak engine power was possible using water injection for both concepts. Just as in the previous section, the turbocharged engine had some advantage due to the lower intake manifold temperatures. It must be noted that allowing a later centre of combustion and/or increasing the water/fuel ratio would leave room for a further increase of the power output until the maximum cylinder head temperature is reached once again. 

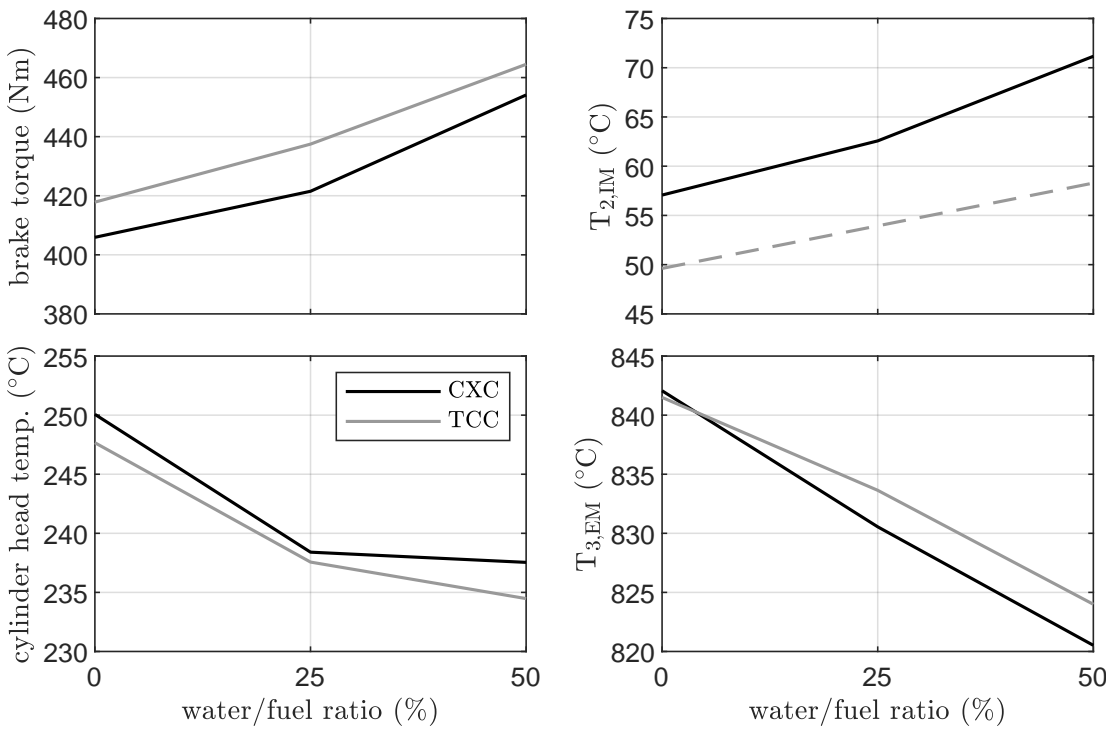

Figure 11. Effects of water injection on the full load at a given centre of combustion of $20^{\circ} \mathrm{CA}$ at an engine speed of $2750 \mathrm{rpm}$.

\subsection{Part-Load Operation}

To quantify the fuel savings potential that result from the use of a Miller camshaft, measurements were taken in the entire operating range in addition to the full-load measurements shown in the previous subsection. Figure 12 shows the part-load results for the configurations Comprex and Miller camshaft (CXM) and Turbocharger and Conventional Camshaft (TCC), respectively, for an engine speed of $2200 \mathrm{rpm}$ where the load was increased from $50 \mathrm{Nm}$ to $350 \mathrm{Nm}$ in steps of $75 \mathrm{Nm}$. For the CXM concept, the power required to drive the Comprex was taken into account. By further optimization of the Comprex, this power demand may be reduced, and at several operating points, it was already negative. The engine speed of $2200 \mathrm{rpm}$ was chosen since low/medium speeds are more relevant for daily operation and, at lower engine speeds, the maximum torque of the turbocharged engine was too low for a comparison over the entire load range.
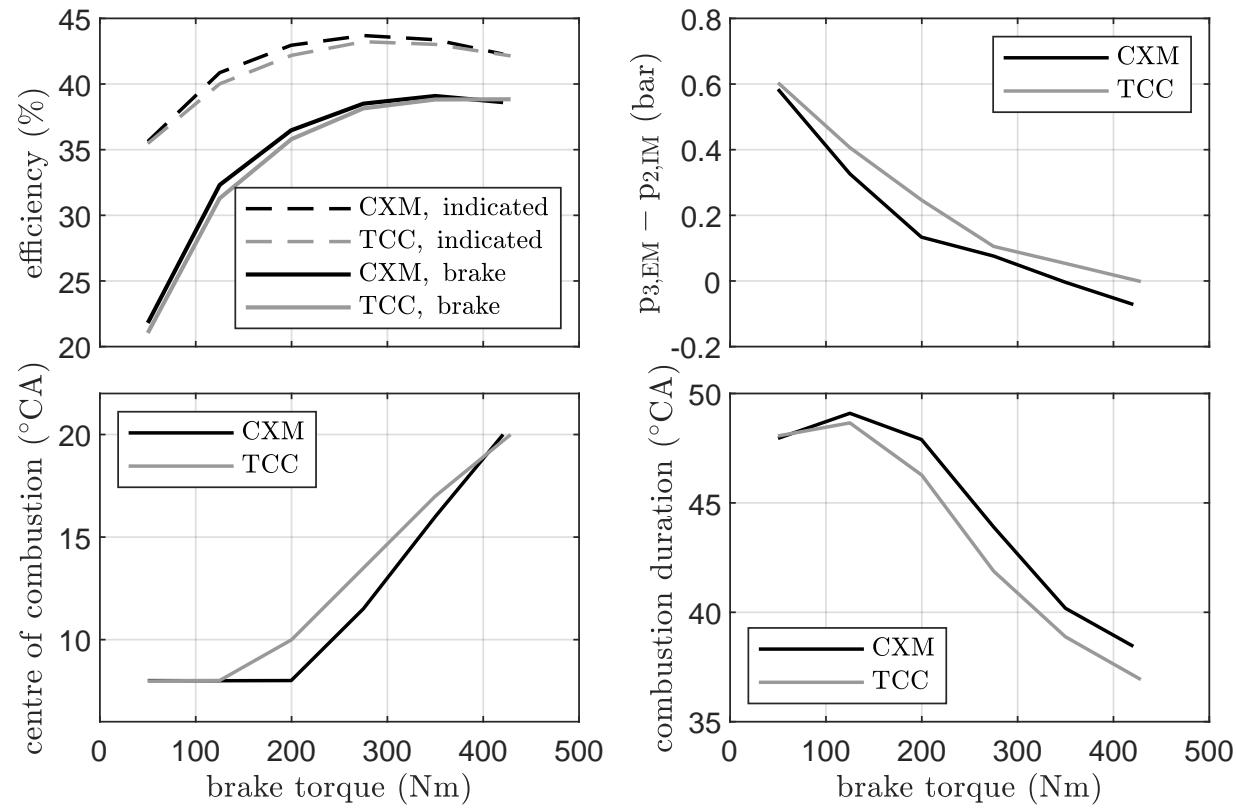

Figure 12. Part-load results of efficiency, gas exchange and combustion for an engine speed of $2200 \mathrm{rpm}$. The highest load point was measured at $2250 \mathrm{rpm}$. 
The indicated efficiency and brake efficiency that were reached with both configurations are shown in the top left subplot. Except for the highest load point, there was always an advantage for the CXM configuration in both the indicated and brake efficiency.

One reason for this improvement was the pressure difference between the exhaust gas backpressure $\mathrm{p}_{3, \mathrm{EM}}$ and the intake manifold pressure $\mathrm{p}_{2, \mathrm{IM}}$, which is shown in the top right subplot. in the entire load range, the pressure difference was favourable in the case of the CXM configuration.

The two bottom plots of Figure 12 show the centre of combustion and the combustion duration, respectively. While the combustion duration increased slightly in the case of the CXM concept, the centre of combustion was closer to the optimal brake value of $8{ }^{\circ} \mathrm{CA}$ except at the highest load point, where in both cases, $20^{\circ} \mathrm{CA}$ was used. The numerical values for the improvements in the brake efficiency that were achieved with the CXM concept are shown in Table 4.

Table 4. Comparison of the concepts in terms of brake efficiency in the relevant load range for the driving cycles.

\begin{tabular}{lccccc}
\hline Brake Torque & $\mathbf{5 0 ~ N m}$ & $\mathbf{1 2 5} \mathbf{~ N m}$ & $\mathbf{2 0 0} \mathbf{~ N m}$ & $\mathbf{2 7 5} \mathbf{~ N m}$ & $\mathbf{3 5 0} \mathbf{~ N m}$ \\
\hline relative improvement & $3.63 \%$ & $3.26 \%$ & $1.87 \%$ & $0.94 \%$ & $0.69 \%$ \\
\hline
\end{tabular}

In addition to these measurements at $2200 \mathrm{rpm}$, measurements for the operating maps were taken at $1000 \mathrm{rpm}, 1600 \mathrm{rpm}, 2800 \mathrm{rpm}$ and $3500 \mathrm{rpm}$. The trends, however, that were shown here were the same for all other engine speeds as well. Except for low engine speeds, where the CXM concept reached much higher brake torque values, it was only the highest load point where the CXM concept had a lower efficiency than the TCC concept. The Miller concept was advantageous at low and medium loads and was enabled by using the Comprex charger.

\subsection{Engine Braking}

Due to the way the Comprex is designed, an engine braking capability is facilitated without the use of additional components such as an exhaust flap. By closing the gas pocket valve(s) successively, the pressure in the exhaust manifold can be increased, which in turn results in a very low (negative) mean indicated pressure.

The engine braking capability is limited by the maximum permissible backpressure of the exhaust system. This pressure limitation results either from the preload of the exhaust valve springs (the valves may not open unintentionally) or from other pressure limitations of the exhaust components (e.g., expansion joint).

For these measurements, the engine was operated at $50 \mathrm{Nm}$ at three different engine speeds, and then, the fuel injection was cut off. The throttle plate was kept at the same position, and the gas pocket valves were closed successively to increase the exhaust backpressure. Measurements were taken up to a torque $<-100 \mathrm{Nm}$ for each engine speed.

Figure 13 shows the results of these measurement series. The left plot shows that there was a linear correlation between the backpressure $p_{3, \mathrm{EM}}$ and the brake torque. Increasing the backpressure also reduced the engine mass flow, which was why the intake manifold pressure $p_{2, \mathrm{IM}}$ slightly increased using the constant throttle position. The right plot shows that these two linearly increasing pressures also resulted in a linearly decreasing Indicated Mean Effective Pressure (IMEP) for each engine speed. These IMEP traces were only offset by the mechanical friction of the engine. During all measurement series, even after several minutes of motored operation, the exhaust gas temperature at the TWC never fell below $180^{\circ} \mathrm{C}$. This can help to reduce the wear of the mechanical brakes and also to keep the exhaust aftertreatment warm during longer phases of motored operation. 

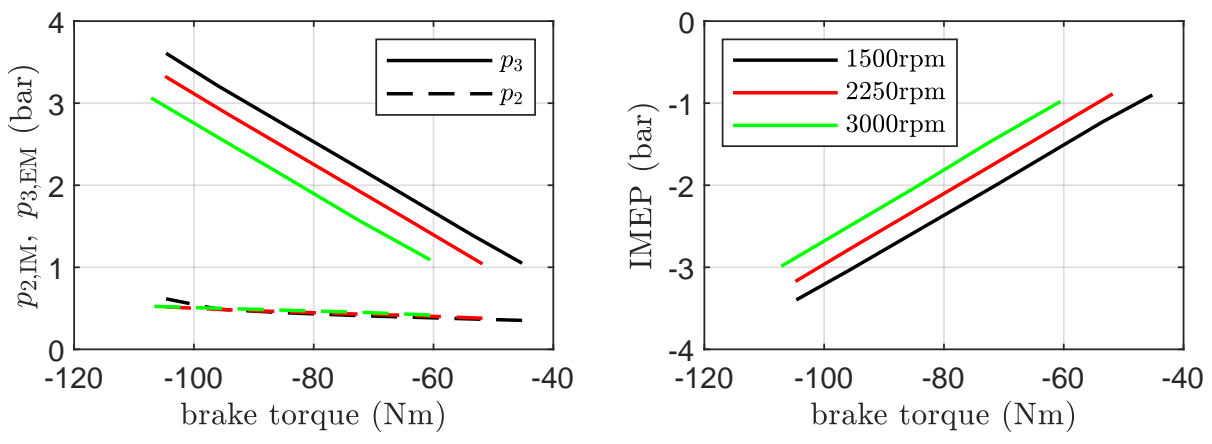

Figure 13. Engine braking with the Comprex. The different colours represent the different engine speeds. In the left subplot, the solid lines show the exhaust gas pressure $p_{3, \mathrm{EM}}$ and the dashed lines show the intake manifold pressure $p_{2, \mathrm{IM}}$.

\subsection{Fuel Consumption in Driving Cycles}

To assess the difference of the resulting fuel consumption in driving cycles of both engine concepts, simulations based on the test bench measurement data were carried out. The driving cycles were simulated with a temporal resolution of one second using a quasi-steady-state framework and both engines were equipped with a stop-start system. The engine cold start and transient engine operation were not included in this framework; however, this type of simulation allowed for a comparison of different concepts.

The main vehicle parameters that were used in the simulation are summarized in Table 5. The driving cycles that are used in the WLTP depend on the power-to-weight ratio of the particular combination of engine and vehicle. Since this engine is used in many different light commercial vehicles that have a maximum weight ranging from $3500 \mathrm{~kg}$ up to $7200 \mathrm{~kg}$, it was relevant to assess the fuel consumption for vehicles of all masses.

Table 5. Main vehicle parameters.

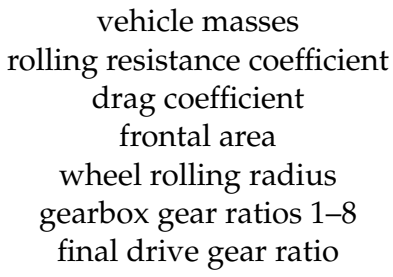

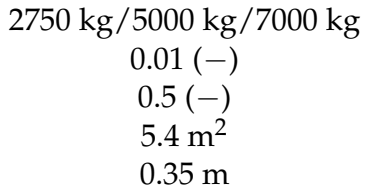

Therefore, simulations were carried out for vehicle weights of $2750 \mathrm{~kg}$, $5000 \mathrm{~kg}$ and $7000 \mathrm{~kg}$, which led to the use of all three of the WLTP's driving cycles. For each engine and driving cycle, the gear shift strategy was determined individually, resulting in the use of higher gears due to the higher low-end torque when the Comprex Miller concept was used. For the vehicle with the Comprex charged engine, the previously described difference in engine braking capacity was taken into account. Downshifting during braking phases to increase the brake torque was not performed for either vehicle.

The driving cycles, the resulting fuel consumption and the reduction in the use of friction brakes are illustrated in Figure 14. The results showed that, in all three cases, fuel savings can be achieved for the CXM concept. The fuel savings were greater for the heavier vehicles, which resulted from the fact that for these vehicles and driving cycles, the top speed and acceleration were lower. This led to a higher fraction of part-load operating points where the Miller concept had greater efficiency advantages. 

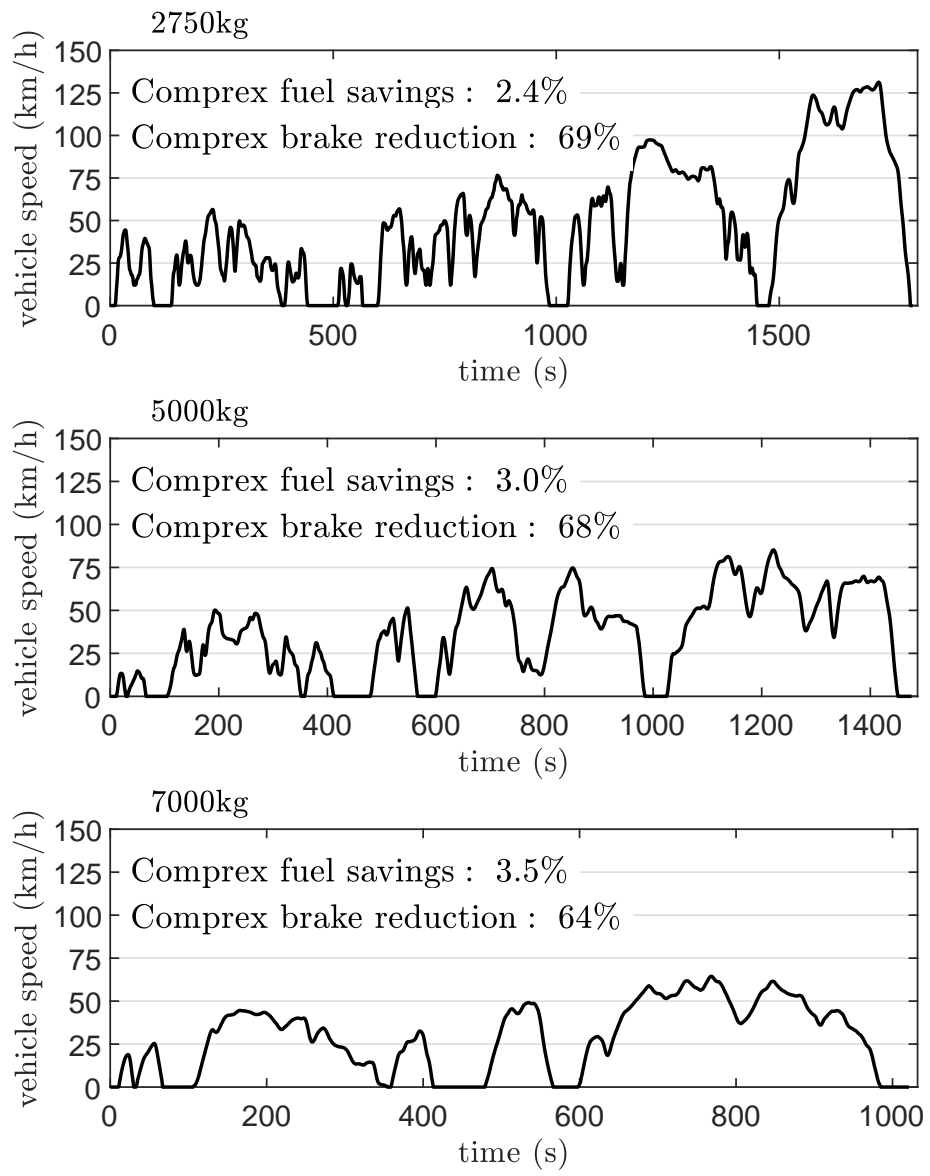

Figure 14. WLTP driving cycles for different vehicle weights (different power-to-weight ratios). The Comprex/Miller concept enables fuel savings for all three driving cycles/vehicle weights and also a reduction of the energy dissipated in the friction brakes.

These results showed that the use of the Comprex/Miller concept was advantageous for all vehicle weights in terms of fuel consumption and also led to a significant reduction in the energy dissipated in the friction brakes due to the engine braking capacity, which is available with the Comprex supercharger. It must be noted that the gear ratios were not adapted to better match the higher low-end torque of the CXM concept. This may lead to an additional benefit for the CXM concept.

\section{Results of Transient Operation}

Besides steady-state operation and quasi-steady-state driving cycles, the transient operation is analysed in this section. In general, the use of a Miller camshaft is detrimental to transient operation for two reasons. On the one hand, a lower mass flow results from the early intake valve closing in the wide-open throttle condition, and on the other hand, a higher boost pressure must be reached for the same torque output. However, one property of a Comprex pressure wave supercharger that has been reported frequently $[13,17,24]$ is that a fast increase of the boost pressure is possible, and another property that was already shown in this paper is that it is very possible to reach a high boost pressure. Therefore, to quantify this somewhat unfair comparison between the Comprex supercharger with a Miller camshaft and the turbocharger with a conventional camshaft, load steps were carried out. In order to assess the transient performance over a wide engine speed range, this was performed at $1250 \mathrm{rpm}, 1750 \mathrm{rpm}, 2250 \mathrm{rpm}$ and $3250 \mathrm{rpm}$, and the resulting torque trajectories are shown in Figure 15. 

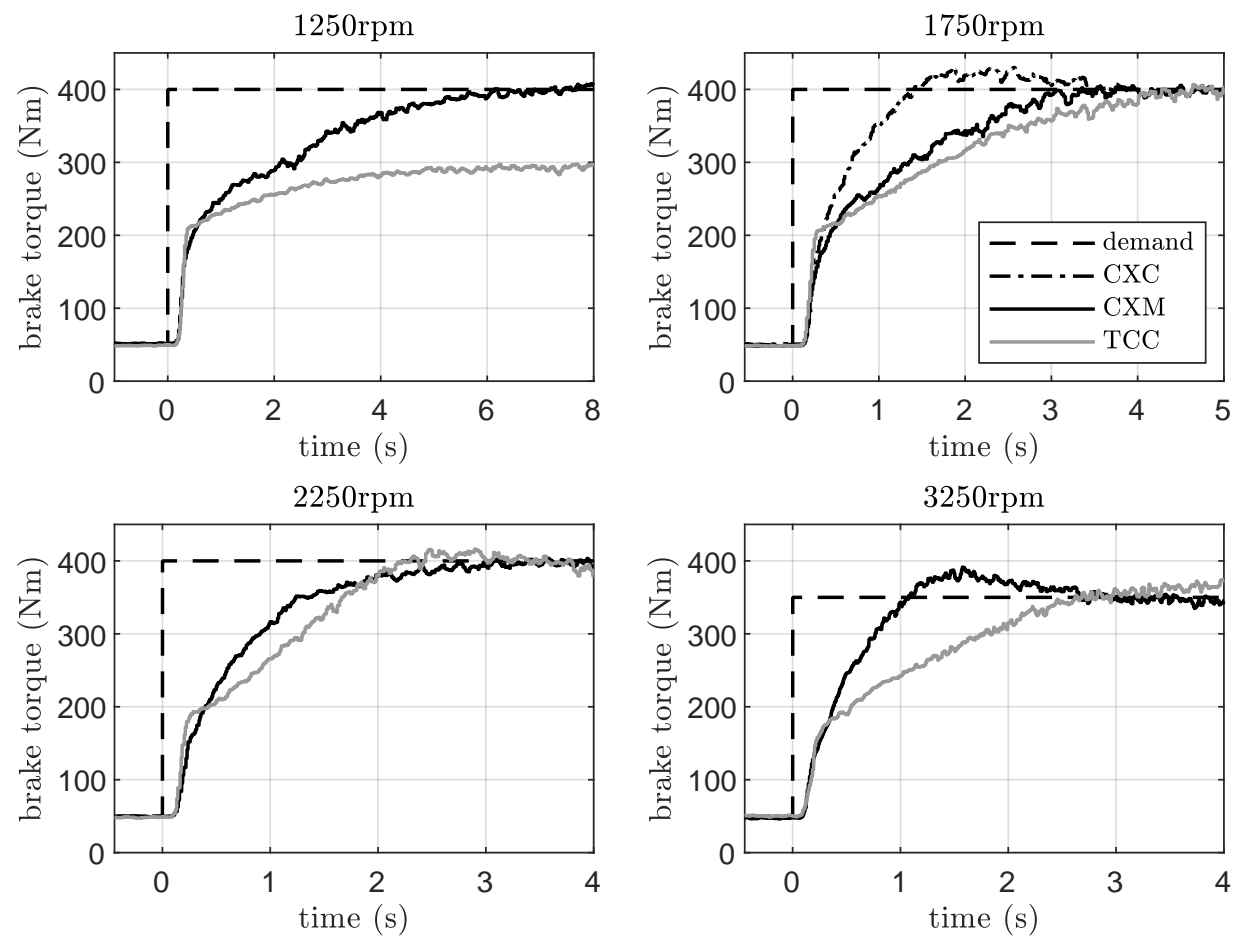

Figure 15. Load steps at several engine speeds using two (three) different engine concepts: Comprex with Miller camshaft (CXM), Comprex with conventional camshaft (CXC) and turbocharger with conventional camshaft (TCC). Notice the different scaling of the x-axes.

Table 6 summarizes the time it took to reach $80 \%$ and $90 \%$, respectively, of the desired torque and also the difference between the two concepts.

Table 6. Rise time until $80 \%$ and $90 \%$, respectively, of the desired torque value is reached. As the load step with the Comprex is always faster, the "relative duration" quantifies the additional time the turbocharged engine requires. At an engine speed of $1750 \mathrm{rpm}$, this was also done with the Comprex and the conventional camshaft $(\mathrm{CXC})$ for comparison.

\begin{tabular}{llll}
\hline Engine Speed & $\boldsymbol{t}_{\mathbf{8 0}} / \boldsymbol{t}_{\mathbf{9 0}} \mathbf{C X M}(\mathbf{C X C})$ & $\boldsymbol{t}_{\mathbf{8 0}} / \boldsymbol{t}_{\mathbf{9 0}} \mathbf{T C C}$ & Relative Duration \\
\hline $1250 \mathrm{rpm}$ & $2.66 \mathrm{~s} / 3.79 \mathrm{~s}$ & $-/-$ & $-/-$ \\
$1750 \mathrm{rpm}$ & $1.61 \mathrm{~s} / 2.28 \mathrm{~s}(0.79 \mathrm{~s} / 1.10 \mathrm{~s})$ & $2.05 \mathrm{~s} / 2.84 \mathrm{~s}$ & $+27 \% /+24 \%(+159 \% /+158 \%)$ \\
$2250 \mathrm{rpm}$ & $1.07 \mathrm{~s} / 1.46 \mathrm{~s}$ & $1.42 \mathrm{~s} / 1.78 \mathrm{~s}$ & $+33 \% /+22 \%$ \\
$3250 \mathrm{rpm}$ & $0.70 \mathrm{~s} / 0.84 \mathrm{~s}$ & $1.46 \mathrm{~s} / 2.01 \mathrm{~s}$ & $+110 \% /+140 \%$ \\
\hline
\end{tabular}

At $1250 \mathrm{rpm}$, the difference in the torque trajectories was the largest because the turbocharged engine was only able to reach $<300 \mathrm{Nm}$, while the Comprex provided enough boost pressure for $>400 \mathrm{Nm}$. At this engine speed, it took less than $3 \mathrm{~s}$ to reach $85 \%$ of the desired torque. During the load step, the Comprex speed increased from $7500 \mathrm{rpm}$ to $11,000 \mathrm{rpm}$, which required approximately $5 \mathrm{~s}$. This led to significant differences between the steady-state and the instantaneous Comprex speed of up to $2300 \mathrm{rpm}$. However, as shown with the Comprex speed variations, this simply led to an increased backpressure and increased temperature for several seconds, which is not a problem. At an engine speed of $1750 \mathrm{rpm}$ and $2250 \mathrm{rpm}$, the response of the turbocharged engine was almost as fast as that of the Comprex. A load step was also carried out with the Comprex and the conventional camshaft at $1750 \mathrm{rpm}$ to assess how significant the disadvantage due to the use of the Miller camshaft was and also to show the potential of the Comprex supercharger. As noted in Table 6, in this case, the time for the torque response of the turbocharged engine was approximately 2.5-times as long as for the Comprex. At $3250 \mathrm{rpm}$, the torque 
response of the Comprex was again significantly faster than that of the turbocharged engine. However, the reason in this case was the pneumatic wastegate actuator that was used for the turbocharged engine, which was rather slow. At the other engine speeds, this was not relevant, since the time for those torque buildups was long compared to the time it took to close the wastegate. At high engine speeds, when the torque increase was faster anyway, the dynamics of the wastegate became relevant.

These results showed that the transient behaviour of the engine equipped with the Comprex supercharger was better than that of its turbocharged counterpart, even if a Miller camshaft was used in combination with the Comprex. When the same camshaft was used for both charging devices, the advantage of the Comprex was greater.

\section{Results of the Aftertreatment System}

Regarding the exhaust aftertreatment system, there are two fundamental differences when a Comprex concept is used. On the one hand, the TWC is placed upstream the boosting device in the high-pressure part of the exhaust system. On the other hand, the OC operates under lean conditions, even if there are stoichiometric conditions at the TWC due to the scavenging of fresh air to the exhaust side. The TWC that was used for this comparison was the same for both concepts, and it was a series production component. The tested turbocharger aftertreatment setup consisted of series production components for both catalytic converters (two-stage TWC), therefore representative of real-life scenarios.

The TWC inlet temperatures and emissions before/after each catalytic converter were measured at various engine operating points across the complete engine map. Additionally, the cold-start behaviour was recorded while the engine warmed up from stand still at a lowload operating point $\left(1000 \mathrm{rpm}, 50 \mathrm{Nm}\right.$ and a centre of combustion of $8{ }^{\circ} \mathrm{CA}$ after top dead centre). These measurements were carried out for both concepts under the same conditions.

The first stage/upstream TWC inlet gas temperatures at various operating points are shown in Figure 16a for both the conventional turbocharger setup (temperatures listed in brackets) and Comprex the setup (temperature listed without brackets). Compared to the conventional turbocharger setup, the TWC in the Comprex aftertreatment layout was subjected to exhaust gases of 25 to $90{ }^{\circ} \mathrm{C}$ higher, due to the catalyst mounting location upstream the Comprex. The higher inlet temperature for the catalyst means better conversion rates in the TWC under the same exhaust gas compositions. The TWC in Comprex setup was mounted at the high-pressure side of the charging device, which means that the residence time of hot exhaust gas was longer compared to the conventional setups. The longer residence time, together with the higher temperature affected the catalyst warmup behaviour.

A significantly faster increase of the TWC outlet temperature for the Comprex setup (top plot in Figure 16b) was observed. The CO conversion rate of the first stage/upstream TWC during the cold start is plotted in the bottom plot of Figure 16b. With the Comprex setup, the time to reach $50 \%$ conversion of $\mathrm{CO}$ was 14.0 seconds, while this time increased to 91.7 seconds with the turbocharger setup (vertical line in Figure 16b). The Comprex setup therefore shortened the light-off time by a factor of six. The authors are aware that this is not a state-of-the-art catalyst warmup strategy. Typically, the centre of combustion is very late during this phase and the fuel energy is used to generate heat in the warmup phase. However, we quantified the difference in this simplified way in order to point out the significant difference in thermal inertia, which is crucial for a fast catalyst warmup regardless of the strategy. A strategy with a late centre of combustion for the Comprex concepts would lead to a very fast catalyst warmup and only be required for a very short period of time, therefore leading to a minimal fuel penalty. As in real-life scenarios, considerable emissions typically result from the cold-start phase [25], the decrease of light-off time with the Comprex setup is a significant advantage in terms of total emissions. 

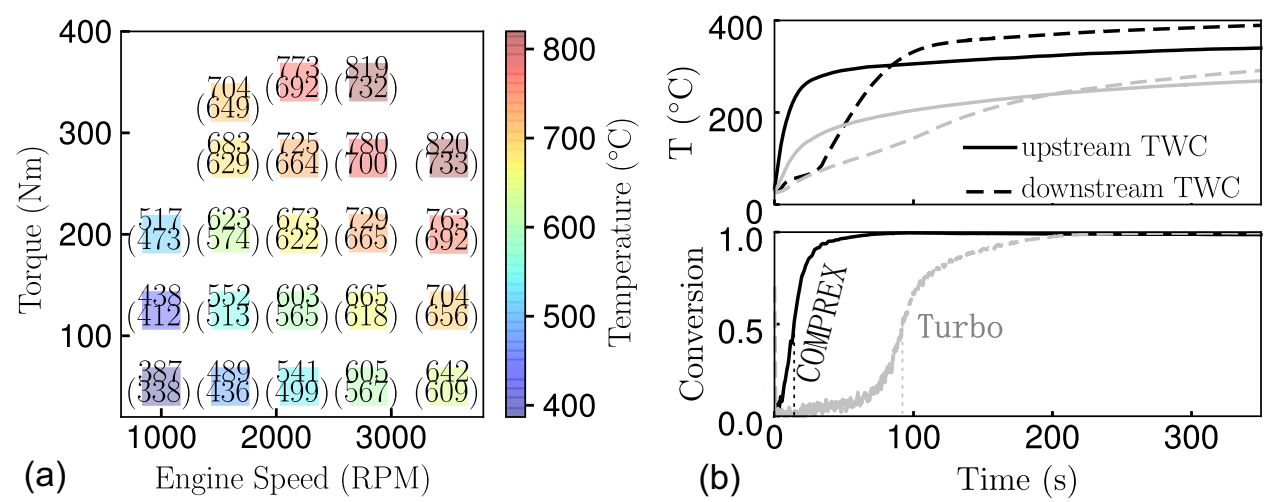

Figure 16. (a) Steady-state temperature upstream the TWC for the Comprex and the turbocharger in brackets. At low engine loads, the centre of combustion was set to $8{ }^{\circ} \mathrm{CA}$ after top dead centre in all cases. (b) Temperature (top) and CO conversion rate (bottom) evolution during cold start at $1000 \mathrm{rpm}$ and $50 \mathrm{Nm}$, centre of combustion $8{ }^{\circ} \mathrm{CA}$ after top dead centre start for the Comprex setup (black) and the turbocharger setup (grey). A Comprex speed of $4000 \mathrm{rpm}$ was used for this cold-start measurement.

The potential of pollutant conversion of the TWC in the Comprex setup system was further studied with steady-state and dithering measurements under several selected operating conditions (tabulated in Table 7). For dithering measurements, the air-to-fuel ratio oscillated around $\lambda=1$ at high frequencies. The conversion rates of major species under steady-state and dithering conditions are plotted in Figure 17a. It is clear that in combination with appropriate dithering strategies, the THC conversion rate stayed above $65 \%$ and the $\mathrm{CO}$ conversion rate above $70 \%$, and the $\mathrm{NO}_{\mathrm{x}}$ was almost $100 \%$ converted. Compared to steady operation, dithering strongly enhanced THC conversion and also promoted $\mathrm{CO}$ conversion, while the engine-out raw emission for steady and dithering operation was rather similar (Figure 17b). The dithering operation, however, led to a high $\mathrm{H}_{2}$ concentration after the TWC (Figure 17c), most likely due to the activation of steam reforming over dithering [26]. Both steady and dithering operations resulted in noticeably high concentration of $\mathrm{NH}_{3}$ after the TWC, which has been reported frequently in research on TWC behaviour under natural gas applications.

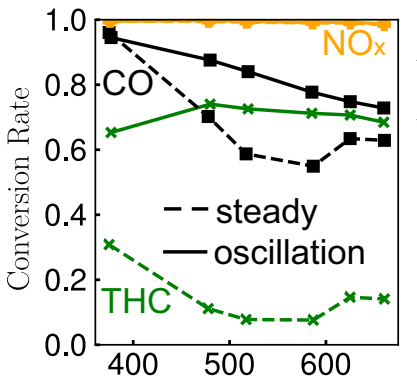

(a) TWC Temperature $\left({ }^{\circ} \mathrm{C}\right)$

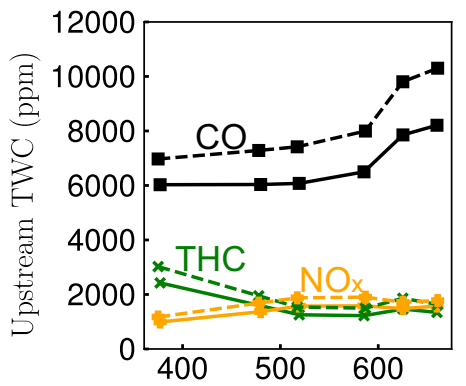

(b)

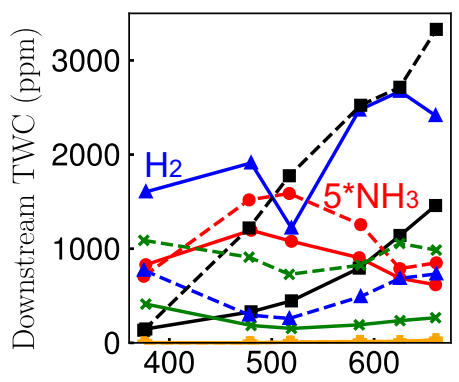

(c)

TWC Temperature $\left({ }^{\circ} \mathrm{C}\right)$

Figure 17. (a) Conversion rates of $\mathrm{NO}_{\mathrm{x}}, \mathrm{CO}$ and THC upstream the TWC; (b) concentration of $\mathrm{CO}$, THC and $\mathrm{NO}_{\mathrm{x}}$ upstream the TWC; (c) concentration of $\mathrm{CO}$, THC and $\mathrm{NO}_{\mathrm{x}}$ downstream the TWC during steady and dithering operations. 
Table 7. Engine operating points with the corresponding temperature at the inlet of the TWC and OC.

\begin{tabular}{cccc}
\hline Engine Speed & Torque & Temperature Inlet TWC & Temperature Inlet OC \\
\hline $1000 \mathrm{rpm}$ & $50 \mathrm{Nm}$ & $375^{\circ} \mathrm{C}$ & $151^{\circ} \mathrm{C}$ \\
$1600 \mathrm{rpm}$ & $50 \mathrm{Nm}$ & $477^{\circ} \mathrm{C}$ & $198^{\circ} \mathrm{C}$ \\
$1600 \mathrm{rpm}$ & $100 \mathrm{Nm}$ & $517^{\circ} \mathrm{C}$ & $232^{\circ} \mathrm{C}$ \\
$2200 \mathrm{rpm}$ & $97 \mathrm{Nm}$ & $586^{\circ} \mathrm{C}$ & $297^{\circ} \mathrm{C}$ \\
$2800 \mathrm{rpm}$ & $80 \mathrm{Nm}$ & $625^{\circ} \mathrm{C}$ & $347^{\circ} \mathrm{C}$ \\
$2800 \mathrm{rpm}$ & $117 \mathrm{Nm}$ & $660^{\circ} \mathrm{C}$ & $397^{\circ} \mathrm{C}$ \\
\hline
\end{tabular}

As described in the previous section, the special design of the Comprex charging system induces a mixture of fresh air and exhaust gas in Channel 4. The remaining $\mathrm{CO}$, dithering-induced excess $\mathrm{H}_{2}$ and $\mathrm{NH}_{3}$ can be removed by oxidation reactions with the additional oxygen in an oxidation catalyst downstream Channel 4. Methane (the main content of the THC in the exhaust) is notoriously difficult to oxidise under lean conditions [27] and was therefore left out of the OC analysis. Figure 18a plots the conversion rates of $\mathrm{H}_{2}, \mathrm{CO}$ and $\mathrm{NH}_{3}$ at the six operating points tabulated in Table 1. The OC inlet temperature was higher than $150{ }^{\circ} \mathrm{C}$ even at the lowest load point $(1000 \mathrm{Nm}, 50 \mathrm{Nm})$, which resulted in nearly $100 \%$ conversion of $\mathrm{CO}$ and more than $80 \%$ conversion of $\mathrm{H}_{2}$ under dithering operation. $\mathrm{NH}_{3}$ is hardly converted at this low temperature. Unsurprisingly, the oxidation conversion increased over temperature. $\mathrm{NH}_{3}$ started to be oxidized at above $200{ }^{\circ} \mathrm{C}$ and reached more than an $80 \%$ conversion rate at around $230{ }^{\circ} \mathrm{C}$ with dithering. The same dithering strategy was also implemented on the turbocharger aftertreatment setup at the same engine operating conditions, which consisted of a second-stage TWC instead of the oxidation catalyst in the Comprex setup. Oxygen was completely consumed in the first stage of the TWC (not shown). Without additional oxygen, the oxidation pathways of the remaining pollutants were blocked. As a result, a significant amount of $\mathrm{CO}, \mathrm{H}_{2}$ and $\mathrm{NH}_{3}$ was detected at the tailpipe.
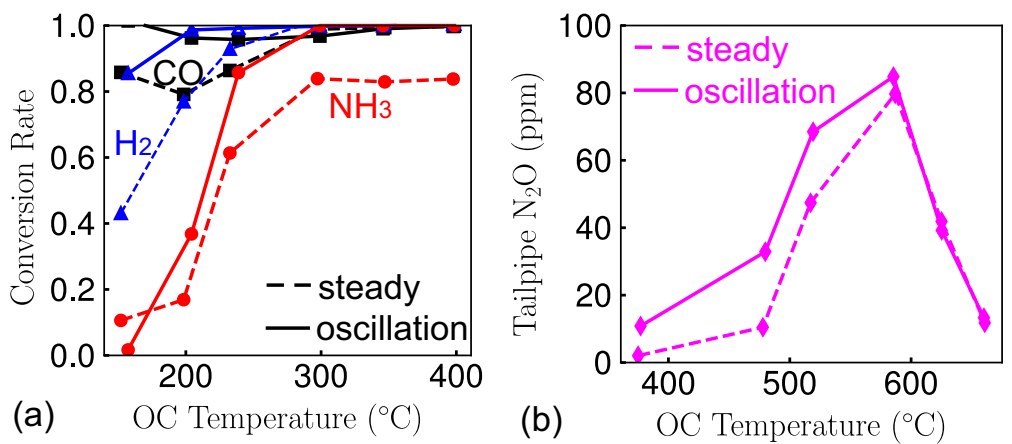

Figure 18. (a) Conversion rates of $\mathrm{H}_{2}, \mathrm{CO}$ and $\mathrm{NH}_{3}$ in the oxidation catalyst; (b) concentration of $\mathrm{N}_{2} \mathrm{O}$ downstream the TWC during steady and dithering operations.

The oxidation catalyst used on the Comprex system is a Pt catalyst, typically used in diesel applications. Even though a Pt-only catalyst is excellent at oxidizing $\mathrm{CO}$, the oxidation of $\mathrm{NH} 3$ with Pt results in undesired products. Figure $18 \mathrm{~b}$ plots the $\mathrm{N}_{2} \mathrm{O}$ concentration at the outlet of the $\mathrm{OC}$ and shows that a noticeable amount of $\mathrm{N}_{2} \mathrm{O}$ was formed during $\mathrm{NH}_{3}$ oxidation. The results suggest that further investigations into alternative catalyst formation are needed to increase the selectivity toward $\mathrm{N}_{2}$ during $\mathrm{NH}_{3}$ oxidation. Nevertheless, the unique layout of the ATS system enabled by the Comprex setup exhibited various advantages over the traditional turbocharger setup. In combination with the targeted dithering strategy, the aftertreatment system delivered a high conversion rate toward THC, $\mathrm{NO}_{x}$ and $\mathrm{CO}$ with the potential benefits of oxidizing the remaining $\mathrm{NH}_{3}, \mathrm{H}_{2}$ and $\mathrm{CO}$ with additional oxidation catalyst downstream. 


\section{Conclusions}

In this paper, we analysed the numerous implications that result from a change from turbocharging to pressure wave supercharging. Two different boosting systems were compared in combination with two different camshafts. The Comprex pressure wave supercharger can provide a high boost pressure already at low engine speeds due to the two-cycle design and is therefore suitable for use with the Miller camshaft (CXM concept). The turbocharged engine on the other hand would have a significantly decreased low-end torque and drivability, which is why here, only the conventional camshaft must be used (TCC concept).

The Comprex's significant advantage with respect to low-end torque comes with a drawback in the maximum power output. Due to a higher fresh air temperature level for this concept and the limitation of the cylinder head temperature, the peak power was $4 \mathrm{~kW}(3.2 \%)$ lower than for the TCC concept. However, this drawback can be overcome by further optimization of the Comprex.

CNG engines that are derived from diesel engines often suffer from temperature limitations. We could show that the power output can be increased significantly regardless of the concept when the cooling effects of port water injection can be utilized.

The use of a camshaft with Miller valve timing led to a better brake efficiency at low and medium loads and to a lower fuel consumption in the driving cycles. This holds true for light commercial vehicles across a wide weight range and all corresponding WLTP driving cycles. The use of the Miller camshaft was enabled by the use of the Comprex pressure wave supercharger.

In addition to the fuel consumption benefits, the Comprex concept also enabled a reduction in the use of the friction brakes by $64-69 \%$. This was due to the design of the Comprex, that enables closing all exhaust gas channels and, hence, utilizing an increased engine braking capability.

The transient performance was compared by means of load steps at constant engine speed. Despite the disadvantages of using a Miller camshaft, the Comprex supercharger yielded better results than the turbocharged engine. When the same camshaft was used for a load step at $1750 \mathrm{rpm}$, the turbocharged engine took 2.5-times as long to reach the same torque.

Finally, the implications of the Comprex concept on the exhaust gas emissions are threefold. A six-times faster catalyst warmup in cold-start conditions was achieved due to the location of the TWC upstream the Comprex. In steady-state operation, the exhaust gas temperature at the TWC was always higher, and also, a postoxidation was possible for the Comprex concept as the mixture was always lean downstream the pressure wave supercharger due to the scavenging in the rotor.

Author Contributions: Conceptualization, N.Z., M.W. and M.A.S.; methodology, N.Z. and P.S.; software, N.Z.; validation, N.Z. and M.W.; formal analysis, N.Z. and M.W.; investigation, N.Z.; resources, P.S. and D.K.; data curation, N.Z.; writing—original draft preparation, N.Z., M.A.S. and M.W.; writing-review and editing, N.Z.; visualization, N.Z. and M.W.; supervision, P.S.; project administration, P.S.; funding acquisition, P.S. All authors read and agreed to the published version of the manuscript.

Funding: This research is part of the project "EMeLi", which is funded by the Swiss Federal Office of Energy, Grant Number SI/501743-01.

Acknowledgments: The authors express their gratitude to Markus Widenhorn, Andreas Nohl and Thomas Roth from Antrova AG and to Roland Graf, Roland Spühler and Hugo Ehrensperger from Empa.

Conflicts of Interest: The authors declare no conflict of interest. 


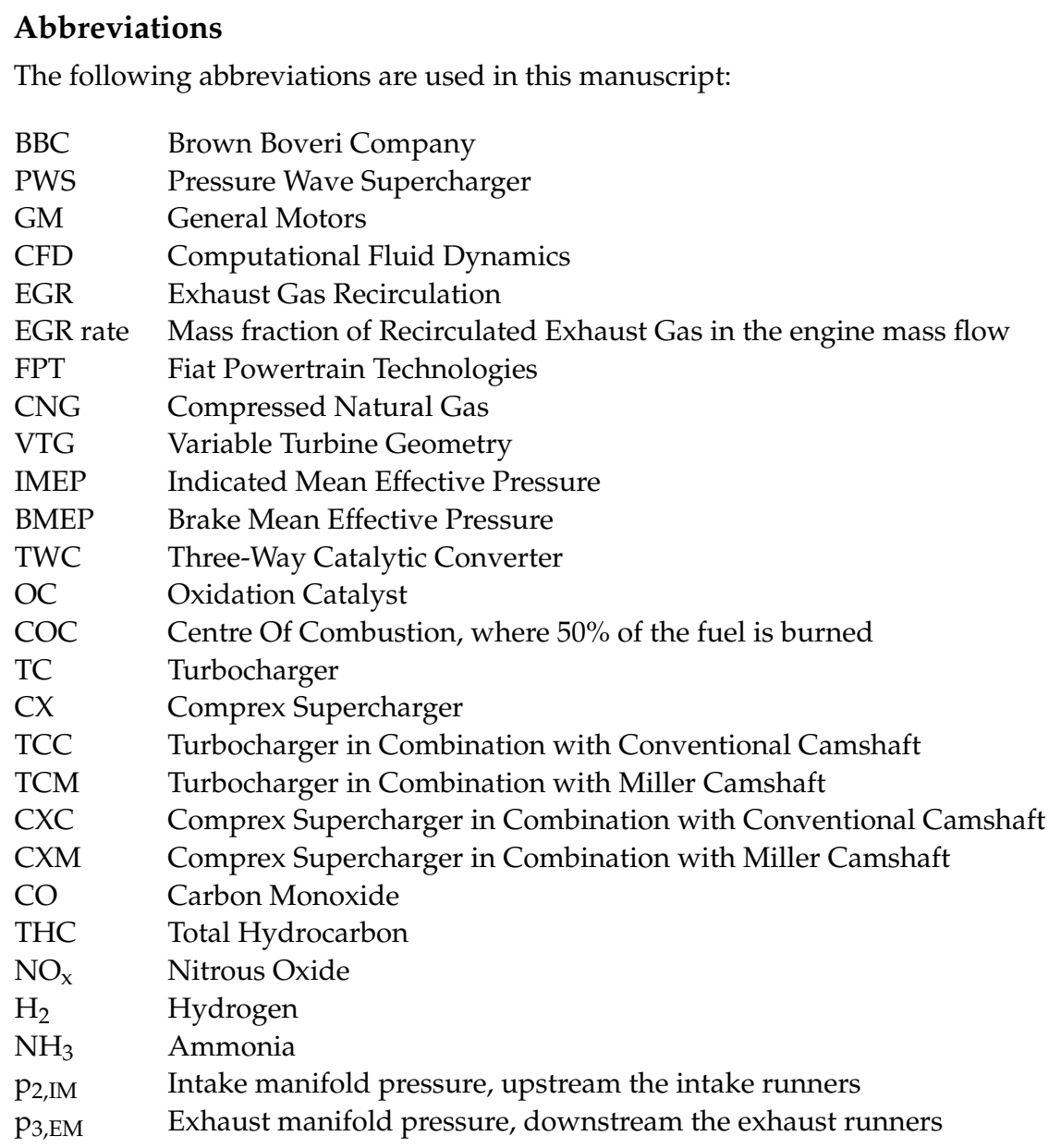

\section{References}

1. Real, R. The 3000 kW Gas Turbine Locomotive Unit. Brown Boveri Rev. 1946, 33, 270-271.

2. $\quad$ ABB-Turbo-Systems-AG. 100 Jahre Turbolader. Turbo Mag. Sonderdr. 2005.

3. Eisele, E.; Hiereth, H.; Polz, H. Experience with Comprex Pressure Wave Supercharger on the High-Speed Passenger Car Diesel Engine; SAE Technical Paper Series; SAE International: Warrendale, PA, USA, 1975. [CrossRef]

4. Zehnder, G.; Mayer, A.; Matthews, L. The Free Running Comprex ${ }^{\circledR}$; SAE Technical Paper Series; SAE International: Warrendale, PA, USA, 1989. [CrossRef]

5. Binder, E. Untersuchungen Zum Potential Eines Verbrennungsmotors Mit Druckwellenlader. Ph.D. Thesis, Technical University Braunschweig, Braunschweig, Germany, 2015. [CrossRef]

6. Flückiger, L.; Tafel, S.; Spring, P. Hochaufladung mit Druckwellenlader für Ottomotoren. MTZ Mot. Z. 2006, 67, 946-954. [CrossRef]

7. Flückiger, L.; Tafel, S.; Spring, P. Pressure-wave supercharged spark-ignition engines. MTZ Worldw. 2006, 67, 6-9. [CrossRef]

8. Skopil, M. Der Druckwellenlader: Mythos Oder Möglichkeit die $\mathrm{CO}_{2}$ Emissionen Stark zu Reduzieren; Motorenkonferenz Baden: Baden, Germany, 2015.

9. Spring, P. Modeling and Control of Pressure-Wave Supercharged Engine Systems. Ph.D. Thesis, ETH Zurich, Zürich, Switzerland, 2006. [CrossRef]

10. Spring, P.; Onder, C.; Guzzella, L. EGR control of pressure-wave supercharged IC engines. Control Eng. Pract. 2007, 15, 1520-1532. [CrossRef]

11. Spring, P.; Piechna, J.; Onder, C.H. Modeling and Validation of a Pressure-Wave Supercharger Using a Finite Difference Method. In Process Industries; ASMEDC: New York, NY, USA, 2004. [CrossRef]

12. Golloch, R. Downsizing. In Downsizing bei Verbrennungsmotoren; Springer: Berlin/Heidelberg, Germany, 2005; pp. 67-146. [CrossRef]

13. Guzzella, L.; Wenger, U.; Martin, R. IC-Engine Downsizing and Pressure-Wave Supercharging for Fuel Economy; SAE Technical Paper Series; SAE International: Warrendale, PA, USA, 2000. [CrossRef]

14. Hagelstein, D.; Theobold, J.; Michels, K.; Pott, E. Vergleich Verschiedener Aufladeverfahren für Direkteinspritzende Ottomotoren; version 10; Aufladetechnische Konferenz: Dresden, Germany, 2005. 
15. Skopil, M. A new Pressure Wave Supercharger Concept for Less Emissions and More Efficiency; Aufladetechnische Konferenz: Dresden, Germany, 2019.

16. Weber, F.; Guzzella, L. Control Oriented Modeling of a Pressure Wave Supercharger; SAE Technical Paper Series; SAE International: Warrendale, PA, USA, 2000. [CrossRef]

17. Weber, F. Mean Value Modeling of a Pressure Wave Supercharger Including Exhaust Gas Recirculation Effects. Ph.D. Thesis, ETH Zurich, Zürich, Switzerland, 2001. [CrossRef]

18. Iancu, F.; Piechna, J.; Müller, N. Basic design scheme for wave rotors. Shock Waves 2008, 18, 365-378. [CrossRef]

19. Kurec, K.; Piechna, J.; Gumowski, K. Investigations on unsteady flow within a stationary passage of a pressure wave exchanger, by means of PIV measurements and CFD calculations. Appl. Therm. Eng. 2017, 112, 610-620. [CrossRef]

20. Hörler, H.U. Abschätzung der Verluste in Instationär-Gasdynamischen Kanaltrommel-Drucktauschern. Ph.D. Thesis, ETH Zurich, Zürich, Switzerland, 1969. [CrossRef]

21. Skopil, M. Hydrogen engines and the new Comprex pressure wave supercharger concept. In Proceedings of the 42nd International Vienna Motor Symposium, Vienna, Austria, 29-30 April 2021.

22. Maiboom, A.; Tauzia, X. NOx and PM emissions reduction on an automotive HSDI Diesel engine with water-in-diesel emulsion and EGR: An experimental study. Fuel 2011, 90, 3179-3192. [CrossRef]

23. Shim, E.; Park, H.; Bae, C. Intake air strategy for low HC and CO emissions in dual-fuel (CNG-diesel) premixed charge compression ignition engine. Appl. Energy 2018, 225, 1068-1077. [CrossRef]

24. Hu, B.; Turner, J.W.; Akehurst, S.; Brace, C.; Copeland, C. Observations on and potential trends for mechanically supercharging a downsized passenger car engine: A review. Proc. Inst. Mech. Eng. Part D J. Automob. Eng. 2016, 231, 435-456. [CrossRef]

25. Pielecha, J.; Skobiej, K.; Kurtyka, K. Testing and evaluation of cold-start emissions from a gasoline engine in RDE test at two different ambient temperatures. Open Eng. 2021, 11, 425-434. [CrossRef]

26. Wang, M.; Eggenschwiler, P.D.; Franken, T.; Ferri, D.; Kröcher, O. Reaction pathways of methane abatement in Pd-Rh threeway catalyst in heavy duty applications: A combined approach based on exhaust analysis, model gas reactor and DRIFTS measurements. Chem. Eng. J. 2021, 422, 129932. [CrossRef]

27. Hutter, R.; Libero, L.D.; Elbert, P.; Onder, C.H. Catalytic methane oxidation in the exhaust gas aftertreatment of a lean-burn natural gas engine. Chem. Eng. J. 2018, 349, 156-167. [CrossRef] 